\title{
Rifting and Arc-Related Early Paleozoic Volcanism along the North Gondwana Margin: Geochemical and Geological Evidence from Sardinia (Italy)
}

\author{
Laura Gaggero, ${ }^{1, \star}$ Giacomo Oggiano, ${ }^{2}$ Antonio Funedda, ${ }^{3}$ and Laura Buzzi ${ }^{1}$ \\ 1. Department for the Study of Territory and Its Resources, University of Genoa, Corso Europa 26, 16132 Genoa, \\ Italy; 2. Department of Botanics, Ecology, and Geology, University of Sassari, Via Piandanna 4, 07100 Sassari, \\ Italy; 3. Department of Earth Sciences, University of Cagliari, Via Trentino 51, 09127 Cagliari, Italy
}

\begin{abstract}
A B S T R A C T
Three series of volcanic rocks accumulated during the Cambrian to Silurian in the metasediment-dominated Variscan basement of Sardinia. They provide a record of the changing geodynamic setting of the North Gondwana margin between Upper Cambrian and earliest Silurian. A continuous Upper Cambrian-Lower Ordovician succession of felsic submarine and subaerial rocks, dominantly transitional alkaline in character (ca. 492-480 Ma), is present throughout the Variscan nappes. Trace element data, together with $\mathrm{Nd}$ isotope data that point to a depleted mantle source, indicate an ensialic environment. A Middle Ordovician (ca. $465 \mathrm{Ma}$ ) calc-alkaline bimodal suite, restricted to the external Variscan nappes, overlies the Sardic Unconformity. Negative $\varepsilon \mathrm{Nd}_{i}$ values $(-3.03$ to -5.75$)$ indicate that the suite is a product of arc volcanism from a variably enriched mantle. A Late Ordovician-Early Silurian (ca. $440 \mathrm{Ma}$ ) volcano-sedimentary cycle consists of an alkalic mafic suite in a post-Caradocian transgressive sequence. Feeder dykes cut the pre-Sardic sequence. The alkali basalts are enriched in $\mathrm{Nb}$ - $\mathrm{Ta}$ and have $\mathrm{Zr} / \mathrm{Nb}$ ratios in the range 4.20-30.90 (typical of a rift environment) and positive $\varepsilon \mathrm{Nd}_{\mathrm{i}}$ values that indicate a depleted mantle source. Trachyandesite lavas have trace element contents characteristic of within-plate basalt differentiates, with evidence of minor crustal contamination.
\end{abstract}

Online enhancements: appendix figures.

\section{Introduction}

An exceptional geodiversity in the Earth history has been evidenced at the Paleozoic, between the two major events of continental accretion that produced Gondwana first and then Pangea (Stampfli et al. 2002; von Raumer and Stampfli 2008; Nance et al. 2010). Thus, the Paleozoic Era begins and ends with a similar geographic configuration, in that one supercontinent is inferred both in the Neoproterozoic and in the Permian. Between the extremes of this Wilson cycle ranging over an interval of 300 million years, the supercontinent Rodinia progressively broke up into macro-microcontinents, which later further fragmented, collided, and subsequently reassembled in Pangea. This process was 2011 .

Manuscript received February 17, 2011; accepted October 19,

* Author for correspondence; e-mail: gaggero@dipteris.unige.it. accompanied by a complex magmatic evolution recorded by a bimodal intraplate volcanism associated with terrigenous sedimentation (Etxebarria et al. 2006; Chichorro et al. 2008; Linnemann et al. 2008), mid-ocean ridge basalt (MORB)-type magmatism associated with lithospheric rifting and oceanization (between Cambrian and Devonian; Murphy et al. 2008, 2011), arc magmatism during subduction and continental collision (Middle Ordovician; Sánchez-García et al. 2003), and postorogenic alkalic magmatism (Upper OrdovicianSilurian boundary; López-Moro et al. 2007; Keppie et al. 2008).

In particular, the significance of the Paleozoic Rheic Ocean to the building of Laurussia and Gondwana continental blocks before the VariscanAlleghanian-Ouachita collision has been recently emphasized and its Cambrian-Paleozoic evolution 
analyzed and dissected along the western, central, and eastern Gondwana margins (Nance et al. 2010).

Despite the occurrence in Sardinia of an almost complete cross section of the Variscan orogen, this segment has barely been included in comprehensive reconstructions of the precollisional history of the Variscan belt, probably due to the scarcity of geochronological and geochemical data on the Sardinian pre-Variscan basement. A set of recent $\mathrm{U}-\mathrm{Pb}$ geochronological data (obtained using excimer laser ablation-inductively coupled plasma mass spectrometry; Oggiano et al. 2010) provides evidence that in Sardinia the precollisional volcanic activity along the North Gondwana margin, or in related terrane assemblages, developed in at least three stages, each stage being characterized by a different geodynamic environment: (1) a Late CambrianEarly Ordovician episode of volcanism (ca. 492-480 $\mathrm{Ma}$ ) within a stratigraphically well-constrained Cambro-Ordovician clastic sequence, (2) Middle Ordovician calc-alkalic activity ascribed to the Dapingian-Sandbian on the basis of paleontology and now dated radiometrically at ca. $465 \mathrm{Ma}$, and (3) an uppermost Ordovician (ca. $440 \mathrm{Ma}$ ) volcanic event of alkaline affinity that is widespread in all the tectonic units of the Sardinian Variscides. In general, however, the various tectonic units are characterized by wide variations in these volcanic rocks in space, time, and volume, and this is typically combined with a lack of adequate age control on the associated clastic sediments. Our interest, therefore, was raised in obtaining more data, valid for reconstruction of the paleogeography and geodynamic events (rifting, breakup, drifting, accretion/hypercollision) related to the northern Gondwana margin and its derived "terranes" over a time period ranging from the Cambro-Ordovician up to the precollisional setting that gave rise to the Variscan configuration of the Mesoeuropean crust. Moreover, the petrology of Paleozoic processes is fundamental to understanding the influence on the lithospheric setting until the Alpine cycle. Diverse sectors of Sardinian Variscides were therefore studied and comparison made with adjacent paleogeographic areas.

The aim of this article is to characterize the geochemical features of the volcanic rocks in order to constrain the source region and crustal evolution, as well as the nature of the geodynamic setting.

\section{Geological Setting}

Present-Day Geological Framework of Sardinia. The Sardinia-Corsica Microplate exhibits one of the most complete and best-preserved transects of the southern European Variscides (Casini et al. 2010), and it can be divided into the following tectonometamorphic zones: a foreland zone in the SW, with either very low-grade or no metamorphism; a nappe zone in the SE and central parts of the island (subdivided into external and internal nappes, with several stacked tectonic units), affected by lowgrade metamorphism; and an inner zone in the north, with medium- to high-grade metamorphism (fig. 1).

The foreland and nappe zones are also characterized by a Middle Ordovician angular unconformity (Sardic Unconformity; Carmignani et al. 2001, and references therein), which is also recognized in the Eastern Iberian Plate (Casas et al. 2010; Navidad et al. 2010). Along the southern boundary of the inner zone, an eclogite-bearing belt is exposed, which was interpreted as a suture zone (Cappelli et al. 1992; Carmignani et al. 1994). The protolith of the eclogite has been dated at $457 \pm 2 \mathrm{Ma}$; the high-pressure event is Devonian (Cortesogno et al. 2004; Giacomini et al. 2005; Franceschelli et al. 2007). These eclogites have MORB signatures and are embedded within a metapelitic-metarenaceous complex hosting also homogeneous quartzite beds (metacherts?), orthogneisses, and metabasite with high- to medium-P granulite metamorphic imprint (Franceschelli et al. 2007). The deformation, localized in low-strength shear zones, and the geometric association of rock bodies with different metamorphic records point to a mélange of rocks tectonically sampled from diverse crustal levels within a channel flow, probably linked to the subduction of a lower Paleozoic ocean (Cappelli et al. 1992; Stampfli et al. 2002; von Raumer et al. 2003).

Throughout the external nappes (Carmignani et al. 1994), the sedimentary record and fossil content is generally preserved, and several volcano-sedimentary complexes are stacked in the nappe zone (Di Pisa et al. 1992; Carmignani et al. 1994; fig. 2).

The Sardinia-Corsica Microplate at the CambroOrdovician Boundary. In the foreland, the preSardic sedimentary history is dominated by the deposition of epicontinental sediments (Nebida Group), including carbonate shelf deposits (Gonnesa Group), which are inferred to grade laterally into deeper siliciclastic sequences (Iglesias Group), all of which are topped by the Sardic Unconformity. The sedimentary rocks of the shelf-slope transition indicate passive continental margin conditions during the Late Cambrian-Early Ordovician (Cocozza 1979; Galassi and Gandin 1992; Pillola et al. 1995, and references therein). Only the Capo Spartivento orthogneiss, basement of the foreland, is referred to this setting, although the error of the available 


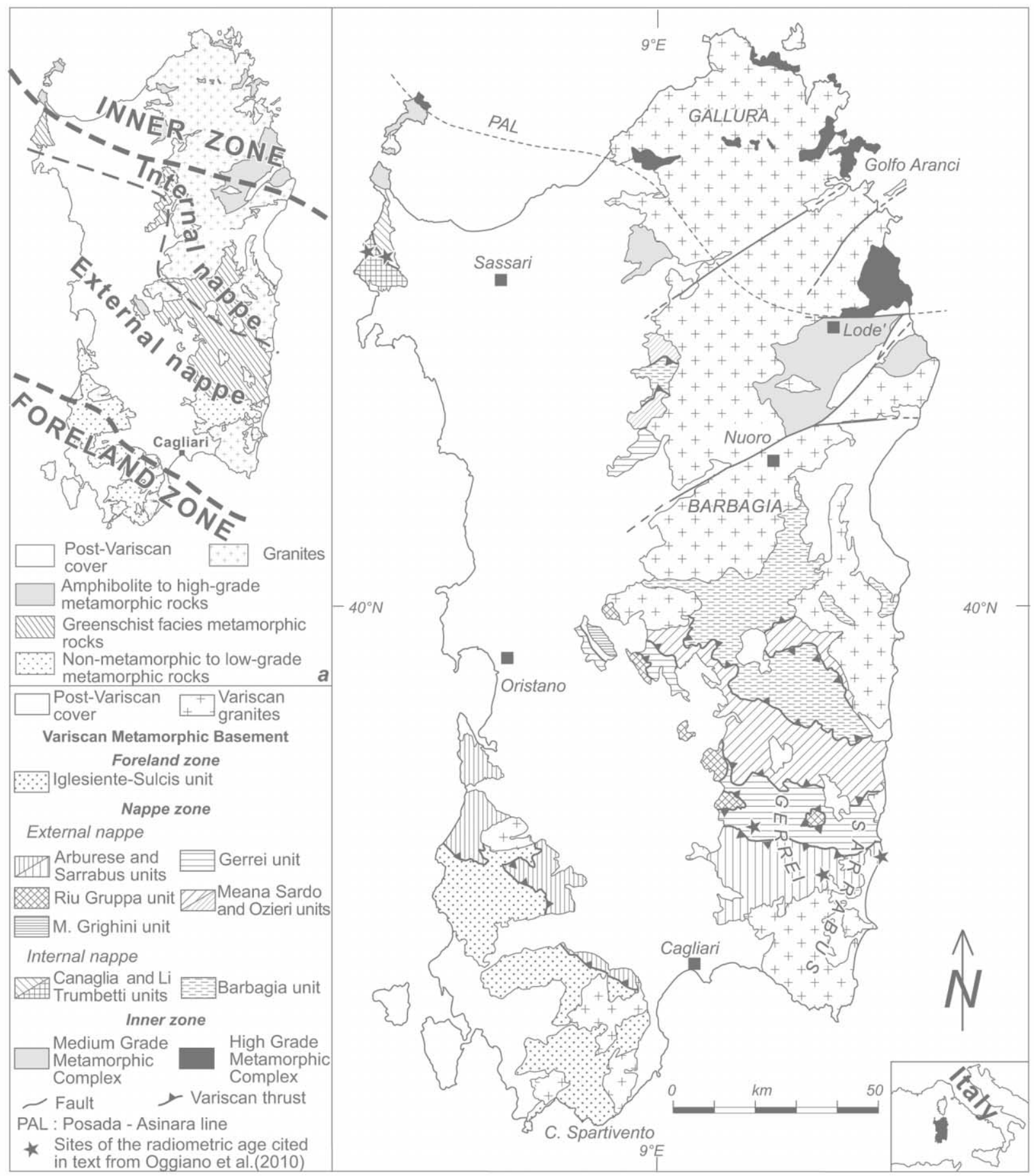

Figure 1. Generalized tectonic map of the Variscan basement of Sardinia and tectonic and metamorphic zones of the Variscan basement of Sardinia $(a)$.

date does not allow a clear age attribution (478 \pm $13 \mathrm{Ma}$; Delaperrière and Lancelot 1989).

The pre-Sardic lithostratigraphic succession of the external nappes consists of metasandstones, phyllites, and quartzites (fig. 2) affected by Variscan pumpellyite-actinolite and lower-greenschist facies metamorphism (Arenarie di San Vito). The ages of the metasedimentary deposits, based on acritarch biostratigraphy, range from Middle Cambrian to Lower Ordovician (Naud and Pittau Demelia 1987). Interbedded in the uppermost part of the succession is a volcanic suite that predates the Sardic Uncon- 


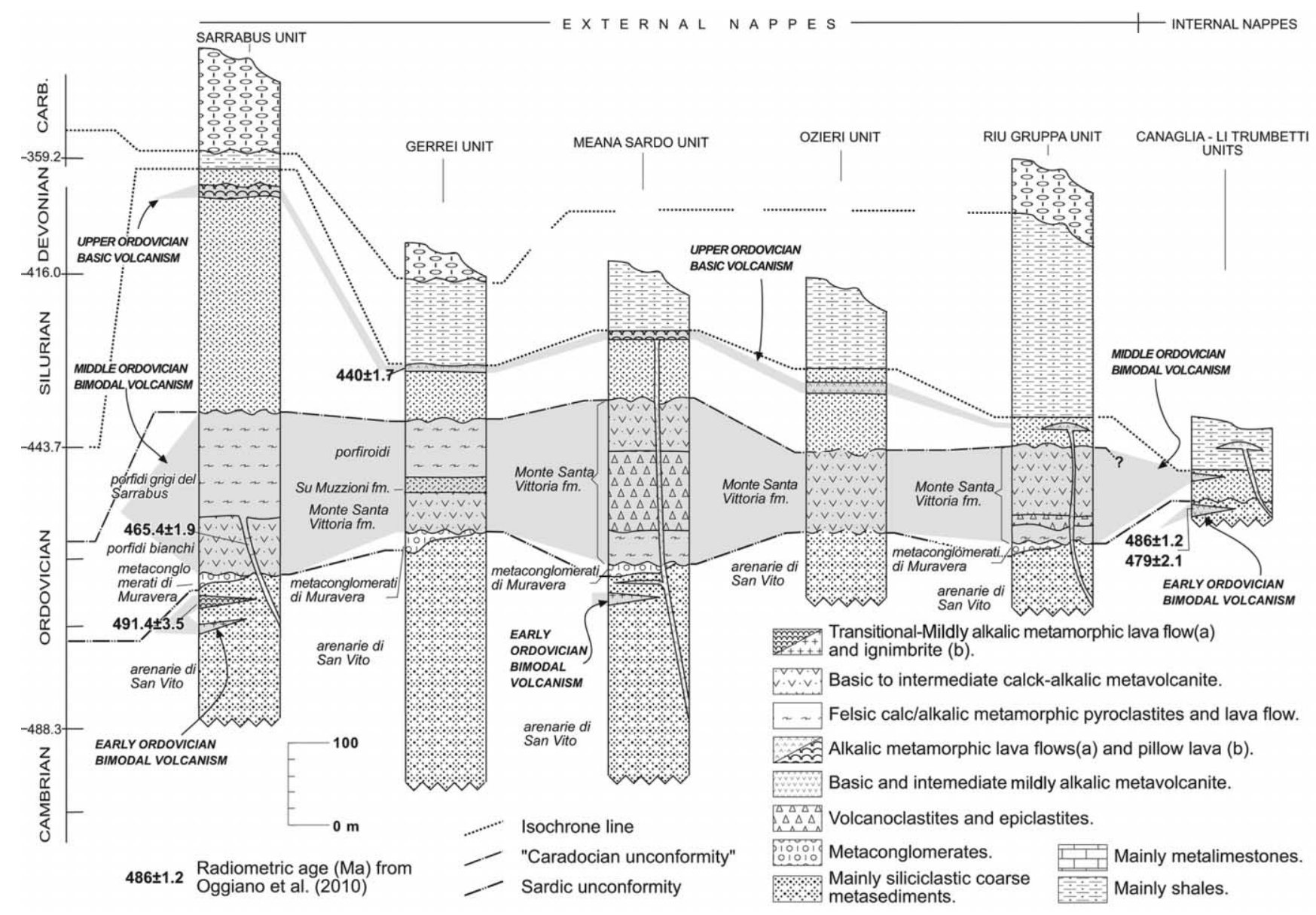

Figure 2. Lithostratigraphic sketch of the relationships within the Lower Paleozoic successions, across the Variscan nappes of Sardinia. The volcanic products are highlighted (after Carmignani et al. 2001; Oggiano and Mameli 2006; Oggiano et al. 2010).

formity (Oggiano et al. 2010); it consists of welded rhyolitic ignimbrites $(491 \pm 3.5 \mathrm{Ma}, \mathrm{U}-\mathrm{Pb}$ zircon age), trachyandesitic pyroclastic fall deposits, and dacite to trachyte lava flows (fig. $3 A$ ). In the Meana Sardo tectonic unit, the volcanic rocks within the pre-Sardic sequence occur as scarce epiclastic crystal-rich tuffites.

In the innermost tectonic units (Li Trumbetti, NW Sardinia), significant volumes of Early Ordovician metavolcanic rocks are preserved, despite the strong deformation and upper-greenschist facies metamorphism (Oggiano and Mameli 2006), and they form meter-thick augen-textured metadacite and metarhyolite lava flows within metasandstones and slates of unknown age. The petrographic similarity of these volcanic rocks to the Middle Ordovician porphyroids led to mistakenly ascribe them to this younger date (Carmignani et al. 1979; Di Pisa and Oggiano 1984), but recent U-
$\mathrm{Pb}$ dating (Oggiano et al. 2010) has now clearly established their Early Ordovician age. This new dating also better constrains on the ages of the Cambrian-Lower Ordovician host metasedimentary rocks (fig. 2).

The Middle Ordovician Succession. The postSardic succession in the foreland starts with huge amounts of continental, alluvial, fan-related conglomerates (M. Argentu Formation; Leone et al. 1991; Martini et al. 1992), and these grade upward into a trangressive sequence made up mostly of sandstone and silt of Katian-Hirnantian age. No volcanic rocks are found in this highstand episode of the post-Sardic phase.

Conversely, in various tectonic units within the nappe zone, an arc-related post-Sardic volcanic suite occurs immediately above thin metaconglomerates (metaconglomerati di Muravera) or directly on top of the pre-Sardic metamorphosed deposits. 


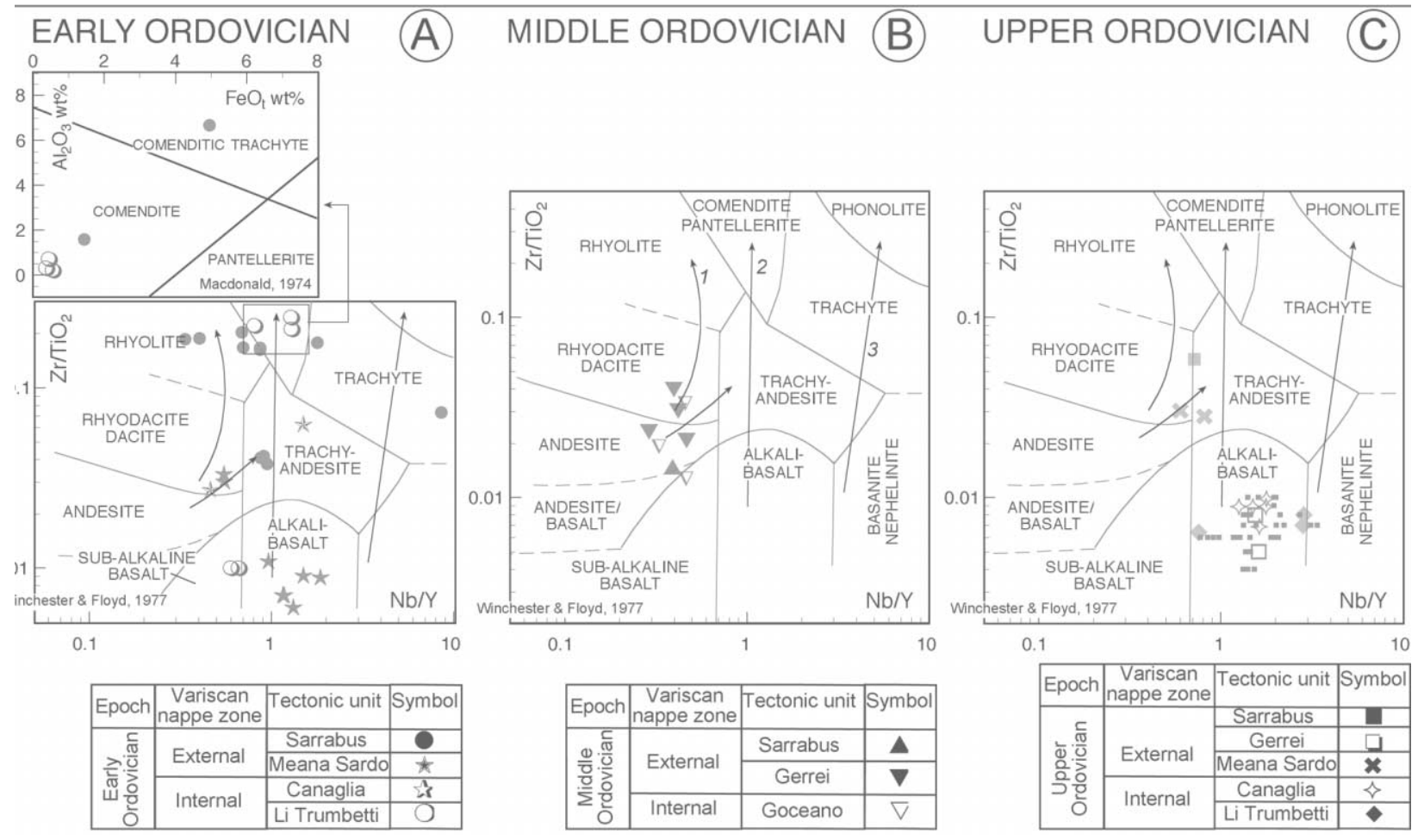

Figure 3. $\mathrm{Zr} / \mathrm{TiO}_{2}$ versus $\mathrm{Nb} / \mathrm{Y}$ diagram (Winchester and Floyd 1977) for volcanic rocks of Early Ordovician $(A)$, Middle Ordovician $(B)$, and Upper Ordovician $(C)$ ages. For comparison, the compositional trends (arrows) of Ararat high-Y (1), Easter Island (2), and Dunedin Volcano (3). In $A$, the compositions that fall in the comendite/pantellerite field on a $\mathrm{Zr} / \mathrm{TiO}_{2}$ versus $\mathrm{Nb} / \mathrm{Y}$ diagram are also reported on the $\mathrm{Al}_{2} \mathrm{O}_{3}-\mathrm{FeO}_{\mathrm{t}}$ classification diagram (Macdonald et al. 1974).

The succession of metandesites that overlies the Sardic Unconformity is associated with subordinate felsic metavolcanics, interlayered coarse meta-epiclastic rocks, and volcanoclastics (Monte Santa Vittoria Formation; Carmignani et al. 2001; inclusive of the Corte Cerbos, Manixeddu, and Serra Tonnai formations of Bosellini and Ogniben 1968). In the decimeter-thick alluvial deposits of the Gerrei tectonic unit, micaceous metasandstones and mature quartz-arenites (Su Muzzioni Formation; Funedda 2000) cap the volcano-sedimentary succession, indicating high erosion rates on the volcanic edifice. In the Sarrabus, Gerrei, and Ozieri tectonic units, the end of this volcanic activity is marked by rhyolite-rhyodacite lavas, ignimbrites, and tuffs, with a combined thickness of $<100 \mathrm{~m}$ (Porfidi grigi del Sarrabus and Porphyroid formation; Calvino 1972). In the outermost nappe zone (i.e., Sarrabus), metadacite occurs as sparse dykes and sills $(465.4 \pm 1.4 \mathrm{Ma}$, U-Pb zircon age; Oggiano et al. 2010) within the pre-Sardic sequences, and they are inferred to be the feeder dykes of the Porfidi grigi del Sarrabus.

The Late Ordovician-Silurian Succession. After the
Middle Ordovician emersion of this sector of the North Gondwana margin, a large-scale transgression marked the onset of a new sedimentary cycle in the Upper Ordovician (Katian-Hirnantian), which then continued through the Silurian and Devonian into the Early Carboniferous. Three main types of volcanic rock (fig. $3 C$ ) are distinguished within the Upper Ordovician terrigenous succession: (1) effusive products (pillow lavas and hyaloclastics), concordant with the host sediments; (2) sills and larger intrusions; and (3) dykes that cut the entire Lower and Middle Ordovician successions.

In the foreland, epiclastic rocks with pebbles of alkaline metabasite (Beccaluva et al. 1981) are associated with the Hirnantian glacio-marine deposits of the San Marco Formation (Leone et al. 1991; Ghienne et al. 2000).

The uppermost Ordovician terrigenous deposits in the external nappes are associated with dykes, sills, and basaltic lavas that locally have pillow structures. Minor layers of epiclastic volcanites crop out close to the Ordovician-Silurian boundary (440 $\pm 1.7 \mathrm{Ma}$; Oggiano et al. 2010). The alkalic 
volcanism is best developed in the inner nappe units (fig. 2), where relatively abundant sills of metadolerite, gabbroic stocks, and meta-epiclastic rocks are widespread within metasiltstones. Ages are constrained by the oolitic ironstones and diamictite associated with the Hirnantian glaciation (Oggiano and Mameli 2006).

\section{Petrography of the Volcanic Suites}

Early Ordovician (492-480 Ma) Bimodal Volcanic Episode. In the Sarrabus Unit, the volcanic products are pyroclastites, lava flows, and welded ignimbrites. The pyroclastic fall deposits are characterized by abundant quartz fragments (porphyritic index $[\mathrm{PI}]=6-14 ; \varnothing=0.6-1.0 \mathrm{~mm}$ ) in a welded tuff matrix. Millimeter-thick quartzofeldspathic laminae suggest sorting by transport. Rare plagioclase phenoclasts $\left(\mathrm{An}_{54-65}\right)$ do not exceed $0.3 \mathrm{~mm}$ in size. The lava flows have abundant quartz, plagioclase $\left(\mathrm{An}_{35-60}\right) \pm \mathrm{K}$-feldspar as the main phenocrystic phases $(\mathrm{PI}=8-10 ; \varnothing=1.2-1.6$ $\mathrm{mm}$ ) in a fine-grained sericitized groundmass. Some polycrystalline quartz xenocrysts also occur. The pyroclastic fall deposits and the lava flows have been pervasively deformed and partially replaced by sericite, chlorite, and subordinate albite + epidote. The welded rhyolitic ignimbrites include crystal and fiamma-rich and glassy eutaxitic facies, which are visible macroscopically as alternating bands of quartz + feldspar and biotite-rich material. The crystal fragments are K-feldspar and quartz, and these are set in a silicic fine-grained and/or glassy devitrified groundmass. Quartz and K-feldspar clasts, overgrown by microcline, are cracked, and the quartz is also subrounded, possibly as a result of thermal corrosion during emplacement. The biotite is largely altered to chlorite + iron oxides. The originally glassy fiammae have been transformed to flattened aggregates of microcrystalline quartz and feldspar. The very low-grade metamorphic overprint resulted in sericite replacing K-feldspar.

In the Meana Sardo Unit, rare dacite flows contain phenocrysts of plagioclase set in a dark groundmass that contains minor quartz. The internal nappes dacite and rhyolite flows are characterized by flattened augen of lobate quartz, plagioclase, and K-feldspar phenocrysts (PI $=4-5 ; \varnothing=0.8 \mathrm{~mm})$, set in a fine-grained groundmass of quartz, feldspar, and phyllosilicates. The flows stratigraphically underlie metabasites with a pervasive schistosity (e.g., the Li Trumbetti Unit). The fine-grained recrystallized groundmass of the metabasites is character- ized by white mica, epidote, chlorite, Fe oxide, and aggregates of albite.

Middle Ordovician (ca. 465 Ma) Bimodal Volcanism. In the Gerrei tectonic unit, the andesite lavas (fig. $3 B$ ) exhibit blasto-porphyritic to glomeroporphyritic textures with plagioclase and biotite phenocrysts set in a fine-grained groundmass. Minor secondary growths of chlorite, white mica, and Fe oxides developed at the expense of biotite, and albite + sericite aggregates at the expense of plagioclase. Generally, the andesites are leucocratic and weakly vesicular, and there are also some horizons of dacitic tuff. The andesites contain abundant plagioclase and quartz phenocrysts and minor biotite and rare K-feldspar fragments.

In the Sarrabus tectonic unit, sparse tabular bodies, intruded into the Cambro-Ordovician succession, are characterized by porphyritic textures with plagioclase, biotite, and embayed quartz phenocrysts set in a fine-grained groundmass that has been partly recrystallized to muscovite, chlorite, albite, and aggregates of Fe oxides. Dacitic and rhyolitic ignimbrites have porphyritic textures with embayed quartz, K-feldspar, and plagioclase, as well as biotite in the dacitic ignimbrites. The welded eutaxitic matrix of the ignimbrites includes pumice fragments recrystallized to sericite, devitrified glass shards, chalcedony-filled amygdales, quartz, albite, and aggregates of mica.

Upper Ordovician-Silurian (440 Ma) Basic-Intermediate Volcanism.In the external nappes, dykes and sills embedded within the transgressive Upper Ordovician sequence are characterized by subrounded quartz and subordinate plagioclase phenocrysts set in a fine-grained quartzo-feldspathic groundmass. Chlorite forms pseudomorphs after biotite. Locally, the rocks have been fractured and cemented by a network of calcite veins. Alkali basalt dykes cut across the pre-Sardic sequence; these were inferred to be the feeder dykes of the Upper Ordovician volcanism (Di Pisa et al. 1992). The dykes display intersertal to porphyritic textures with plagioclase phenocrysts. Skeletal ilmenite and apatite occur, titano-magnetite has replaced ilmenite, and mafic phases and the groundmass are altered to chlorite, epidote, and $\mathrm{Fe}$ oxides. In the outermost unit (the Sarrabus Unit), plagioclase-bearing $\left(\mathrm{An}_{45-48}\right)$ pillow lavas contain olivine microphenocrysts preserving the pristine mesh texture that are replaced by chlorite, diopside that is rimmed by hornblende and ilmenite, and a glassy to fine-grained intersertal groundmass with sparse calcite-filled vacuoles. Fibrous blue-green amphibole develops in the outer shell of the pillows and in fractures and veins. The 
pillow lavas are in contact with metamorphic strata that are spotted as a result of a pre-Variscan thermal overprint. The spots were probably andalusite originally but are now stilpnomelane.

In the internal nappes, the Ordovician succession in the Canaglia Unit is cut by meter-thick sills of hornblende-gabbro (fig. 3C), in part reequilibrated under the greenschist facies. The sills show orthocumulus textures, with euhedral seriate plagioclase and accessory Fe oxides with intercumulus hornblende. The coarser plagioclase grains are broken and sutured by newly precipitated feldspar or bent, thus providing evidence of a syn-magmatic deformation. Plagioclase-rich diorite veins cut the gabbro body.

\section{Geochemistry of the Volcanic Suites}

Analytical Methods. Forty-four rock samples were collected from the tectonic units described above, and they were selected to represent different occurrences and timing of events. The samples were analyzed for major and trace elements using the X-ray fluorescence facilities at SGS Laboratories. Loss on ignition was determined with the gravimetric method. The rare earth elements (REEs) were analyzed using inductively coupled plasma mass spectrometry at SGS Laboratories. The bulkrock compositions for Sardinian volcanic rocks of Early, Middle, and Upper Ordovician ages are included in the repository data.

Twenty-seven of the rock samples were selected and analyzed for $\mathrm{Sr}$ and $\mathrm{Nd}$ isotopes at the Geochemistry Laboratory of Trieste University. Samples were dissolved in Teflon vials for isotopic analysis using a mixture of purified $\mathrm{HF}-\mathrm{HNO}_{3}$ and $\mathrm{HCl}$ reagents. Sr and $\mathrm{Nd}$ were collected after ion exchange and reversed-phase chromatography, respectively; the total blank for Sr was $<20 \mathrm{pg}$. The $\mathrm{Sr}$ and $\mathrm{Nd}$ isotopic compositions were obtained using a VG 54E mass spectrometer and Analyst software (Ludwig 1994) for data acquisition and reduction. The ${ }^{87} \mathrm{Sr} /{ }^{86} \mathrm{Sr}$ and ${ }^{143} \mathrm{Nd} /{ }^{144} \mathrm{Nd}$ ratios were fractionation corrected to ${ }^{86} \mathrm{Sr} /{ }^{88} \mathrm{Sr}=0.1194$ and ${ }^{146} \mathrm{Nd} /{ }^{144} \mathrm{Nd}=0.7219$, respectively, and the measured ratios were corrected for instrumental bias to NBS 987 and JNdi-1 standard values of 0.71025 and 0.512100 . Repeated analyses of the NBS 987 and JNdi-1 standards gave average values of $0.71025 \pm 0.00002 \quad(n=15)$ and $0.51211 \pm$ $0.00002(n=10)$, and no corrections were applied to the measured data for instrumental bias. The reported errors represent the $95 \%$ confidence level.

Geochemical Features of the Volcanic Products. In determining the pristine chemistry of an altered igneous rock, it is important to consider the possibility of chemical transformations that resulted from contact with the host metasedimentary rocks or from early diagenetic processes, especially in effusive rocks. In addition, the effects of element mobility during tectonism and metamorphism /which here includes pumpellyite to amphibolite facies overprints) have been considered. Primary compositional heterogeneities, observed in textures and the modal distribution of minerals, were avoided in sampling, as well as the occurrence of carbonates and hydrous phases, which indicate fluid-induced modifications. Nevertheless, meso- and microscopic observations generally enable the correlation of mineral phases and bulk rock compositions. The samples analyzed were selected with these points in mind, but caution is still required when interpreting the data.

Late Cambrian-Early Ordovician Volcanism. The Early Ordovician metavolcanic rocks are mainly silicic $\left(52.4-84.1 \mathrm{wt} \% \mathrm{SiO}_{2}\right.$ on an anhydrous basis) and are weakly to strongly peraluminous with an aluminium saturation index (ASI = $(\mathrm{Al} / \mathrm{Ca}-1.67)(\mathrm{P}+\mathrm{Na}+\mathrm{K}) ; \mathrm{Zen} 1988)$ in the range 1.1-3.4. The nature of their protolith is indicated by using a $\mathrm{Zr} / \mathrm{TiO}_{2}$ versus $\mathrm{Nb} / \mathrm{Y}$ classification diagram (Winchester and Floyd 1977; fig. 3A), where the data define a mildly alkaline trend. The lava flows consist of subalkalic basalt, dacite, trachyandesite, trachyte, and comendite. The ignimbrites have rhyolitic and comenditic trachyte compositions $\left(\mathrm{Al}_{2} \mathrm{O}_{3}\right.$ vs. $\mathrm{FeO}_{\text {tot; }}$ Macdonald et al. 1974), whereas the pyroclastic fall deposits are trachyandesitic. Overall, they define linear fractionation trends with negative correlations of $\mathrm{TiO}_{2}, \mathrm{Al}_{2} \mathrm{O}_{3}$, $\mathrm{K}_{2} \mathrm{O}$, and $\mathrm{Rb}$ with $\mathrm{SiO}_{2}$ (fig. 4). The scatter for $\mathrm{K}_{2} \mathrm{O}$ suggests that mica is the major component of the fractionating assemblage, because of the generally incompatible behavior of $\mathrm{Rb}$ in K-feldspar within peraluminous melts (Icenhower and London 1996).

Most lava flows and ignimbrites are characterized by a slight fractionation of light REEs (LREEs; $\left.\mathrm{La}_{\mathrm{CN}} / \mathrm{Sm}_{\mathrm{CN}}=1.14-6.71\right)$ and negative Eu anomalies, which become more pronounced toward evolved compositions (fig. 5A). In trachyandesitic pyroclastic rocks and trachyte lava, the negative $\mathrm{Eu}$ anomaly is absent, and there is significant heavy REE (HREE) fractionation $\left(\mathrm{Gd}_{\mathrm{CN}} / \mathrm{Yb}_{\mathrm{CN}}=0.67-\right.$ 14.31). The positive correlation of REE with $\mathrm{SiO}_{2}$ suggests minor fractionation of REE-rich accessory phases.

In the primitive mantle-normalized multielement diagram, the trace element patterns of the 

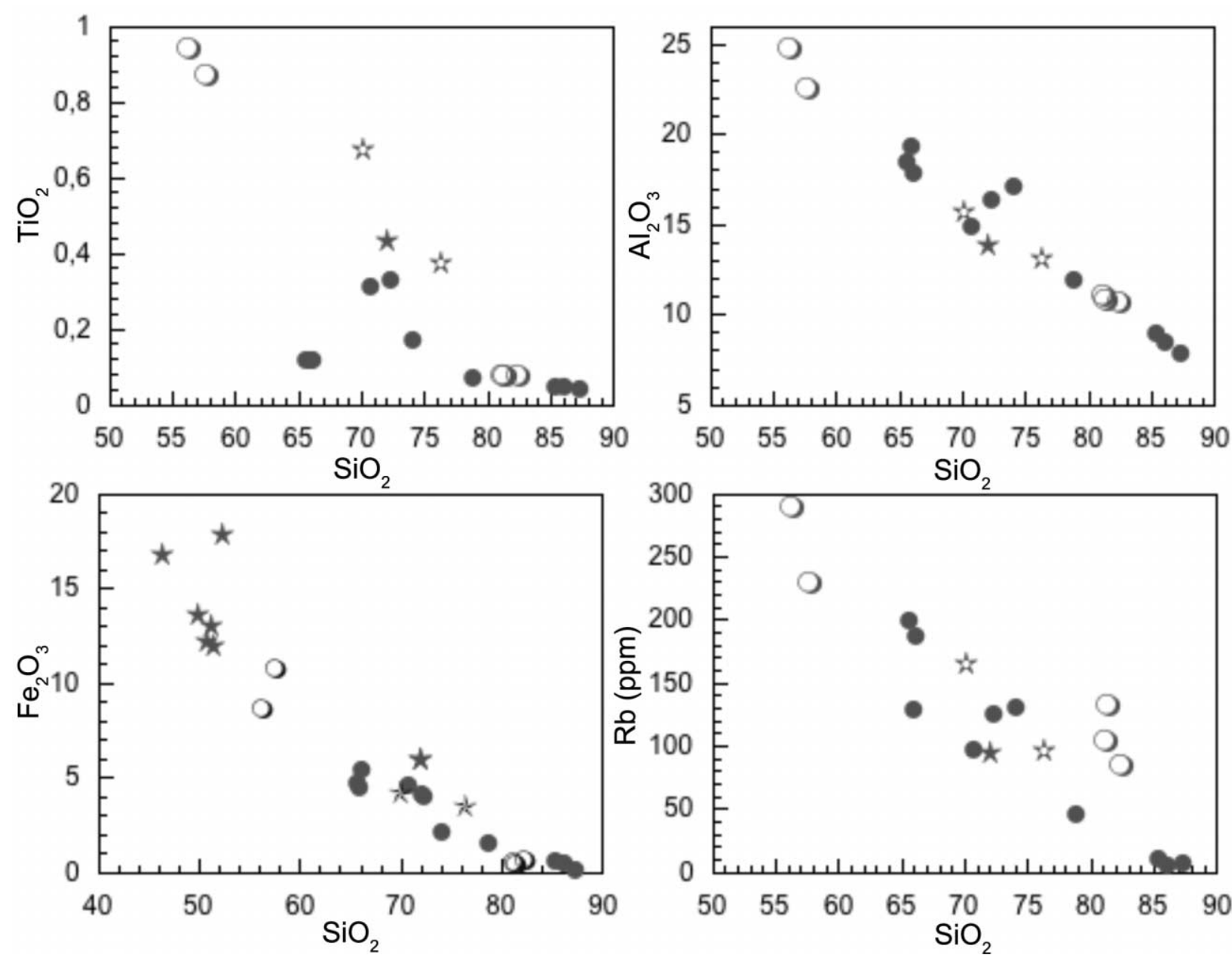

Figure 4. $\mathrm{Al}_{2} \mathrm{O}_{3}, \mathrm{Fe}_{2} \mathrm{O}_{3 \mathrm{t}}, \mathrm{K}_{2} \mathrm{O}, \mathrm{P}_{2} \mathrm{O}_{5}, \mathrm{TiO}_{2}$, and $\mathrm{Rb}$ versus silica diagrams for Early Ordovician volcanic rocks. Filled symbols correspond to the external Variscan nappe zone (circle, Sarrabus tectonic unit; star, Meana Sardo tectonic unit). Open symbols correspond to the Internal Variscan nappe zone (circle, Li Trumbetti tectonic unit; star, Canaglia tectonic unit). See also figure A1, available in the online edition or from the Journal of Geology office.

subalkali basalts are characterized by an overall large ion lithophile element (LILE) and LREE enrichment, fractionation between LILEs, high field strength elements (HFSEs) and LREEs/HREEs (fig. $6 A$ ), Ba depletion, a Ta-Nb trough, a marked negative $\mathrm{Sr}$ anomaly, and a negative $\mathrm{Eu}$ anomaly (Eu/Eu* up to 0.63$)$, all of which suggest that the melts experienced some degree of plagioclase fractionation.

Middle Ordovician Volcanism. The Middle Ordovician volcanic rocks consist of a calc-alkaline suite of andesites, dacites, and rhyolites (fig. 3B). Andesites have low Mg\# values (32-24) and very low Ni (7-48 ppm) and Cr contents (66-137 ppm). The positive correlations of $\mathrm{K}_{2} \mathrm{O}, \mathrm{Ba}$, and $\mathrm{Rb}$ versus silica (fig. $4 B$ ) reflect the role of K-feldspar and/or mica in fractionation. Fractionated chondrite-normalized REE patterns $\left(\mathrm{La}_{\mathrm{CN}} / \mathrm{Yb}_{\mathrm{CN}}=6.22-12.44\right)$ with negative $\mathrm{Eu}$ anomalies $\left(\mathrm{Eu} / \mathrm{Eu}^{*}=0.53-0.79\right)$ are evident (fig. 5B).

In the primitive mantle-normalized multielement diagram, the trace element patterns show enrichment in LILEs and LREEs, associated with LILE/HFSE and LREE/HREE fractionation, and Ta$\mathrm{Nb}, \mathrm{Sr}, \mathrm{P}$, and Ti troughs (fig. 6B). Andesitic tuffs are the least LILE enriched.

Upper Ordovician-Silurian Volcanism. The Upper Ordovician lava flows, sills, and dykes are mostly alkali basalt, but there are also some trachyandesite pillow lavas (fig. $3 \mathrm{C}$ ). The alkali basalts have $\mathrm{SiO}_{2}$ contents between 44.5 and $51.9 \mathrm{wt} \%$ and $\mathrm{Mg \#}$ values in the range 43-15. Fractionated REE patterns $\left(\mathrm{La}_{\mathrm{CN}} / \mathrm{Yb}_{\mathrm{CN}}=3.23-12.99\right)$ with positive or no Eu anomalies are evident (fig. $5 C$ ). The high REE contents and positive Eu anomalies could represent melts that experienced significant hornblende/cli- 


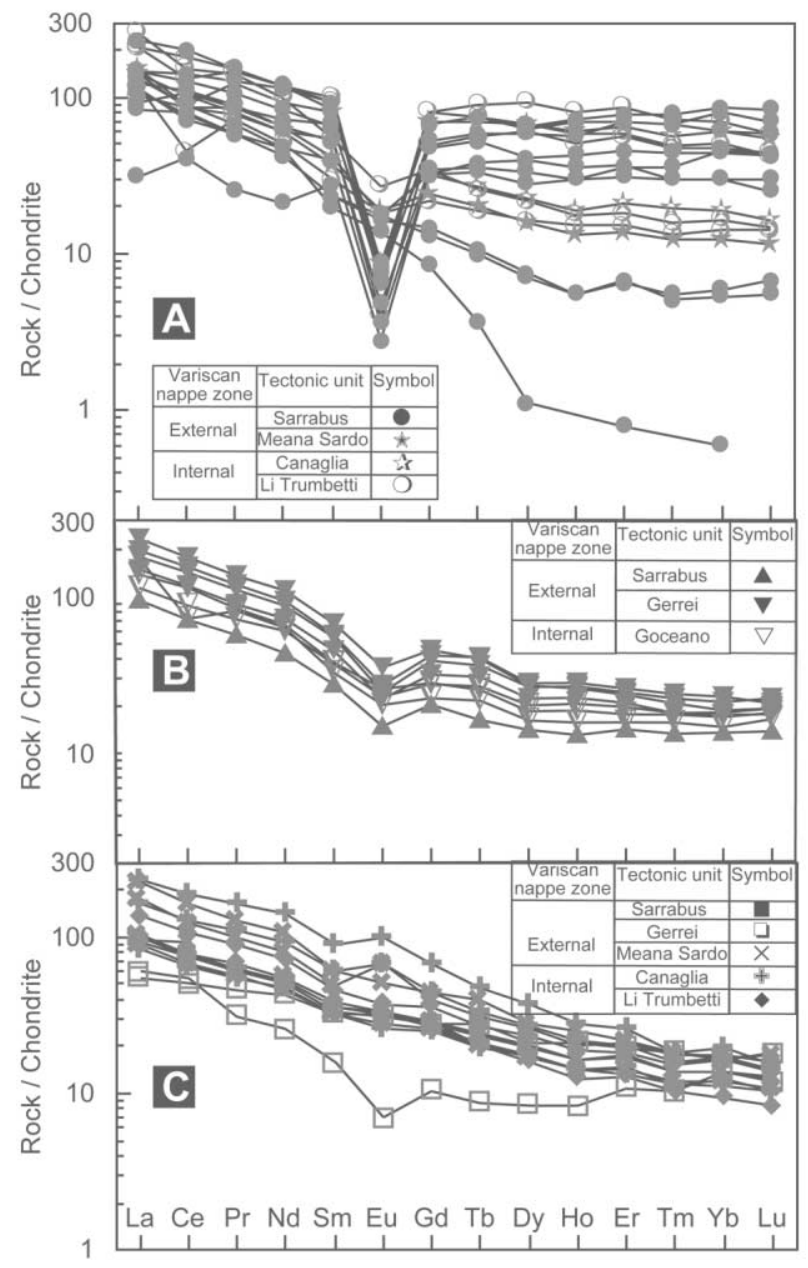

Figure 5. Rare earth element patterns normalized to primitive mantle (Sun and McDonough 1989) for volcanic rocks of Early Ordovician $(A)$, Middle Ordovician $(B)$, and Upper Ordovician $(C)$ ages.

nopyroxene fractionation, while negligible $\mathrm{Eu}$ anomalies could be produced by equal proportions of plagioclase and hornblende/clinopyroxene fractional crystallization (Hanson 1980).

However, the primary composition of the 440Ma metavolcanic rocks could have been affected by element mobilization during metamorphism or, to some extent, during weathering, as indicated by petrography and loss on ignition values up to $10 \%$. Weathering could affect the concentration of the most incompatible elements (e.g., $\mathrm{Rb}, \mathrm{Ba}$, and $\mathrm{K}$ ), which are known to be mobile under surface alteration. This possibility is indicated for alkalibasalts, which display a considerable scatter of LILEs in the primitive mantle-normalized multielement diagram (fig. 6C). The patterns reveal mainly $\mathrm{Rb}$ and $\mathrm{K}$ troughs relative to $\mathrm{Ba}$ and $\mathrm{Th}$ (however, $\mathrm{Rb}$ and $\mathrm{K}$ enrichments are observed in samples ORD32 and ORD44). In general, there is an overall $\mathrm{Ta}$ and $\mathrm{Nb}$ enrichment relative to $\mathrm{La}$, a fractionation between LREEs and HREEs, and a negative $\mathrm{Sr}$ anomaly (except for sample ORD42).

Trachyandesite and dacite lavas have REE abundances that lie within the range for alkali basalts

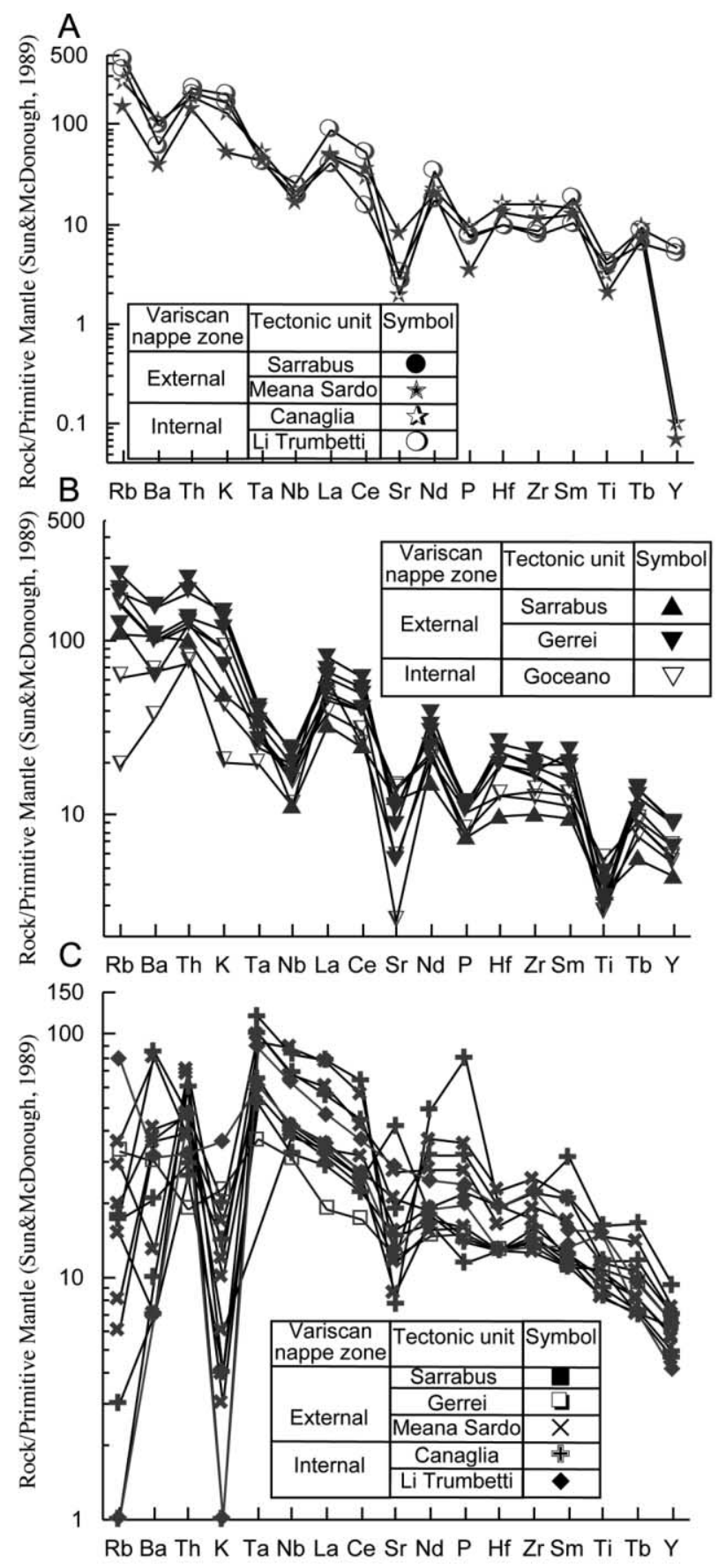

Figure 6. Multielement diagrams normalized to primitive mantle (Sun and McDonough 1989) for mafic volcanic rocks of Early Ordovician $(A)$, Middle Ordovician $(B)$, and Upper Ordovician $(C)$ ages. 


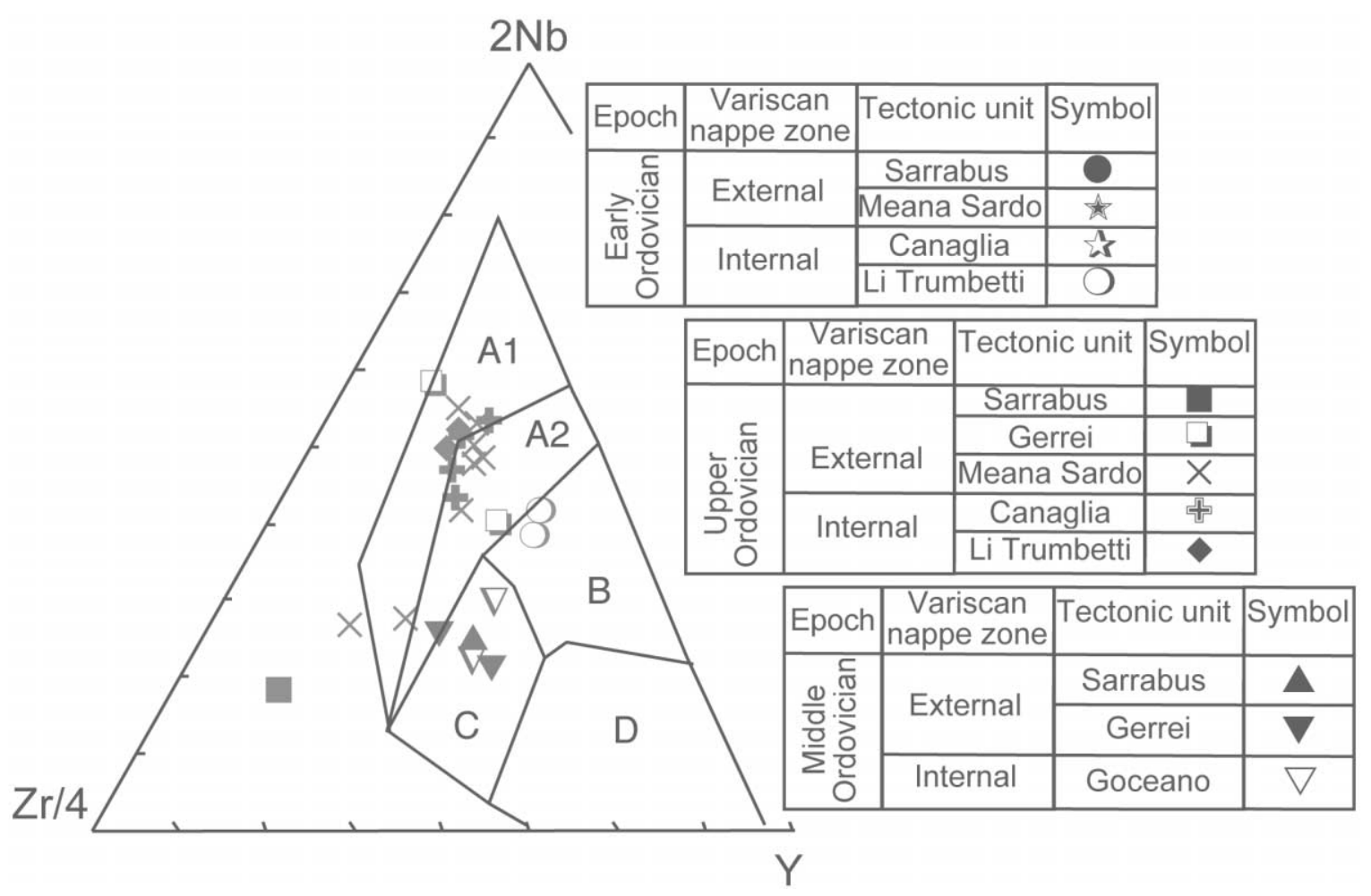

Figure 7. Early, Middle, and Upper Ordovician mafic volcanics from Sardinia plotted on the Zr-Nb-Y discrimination diagram (Meschede 1986). A1, within-plate alkali basalts; $A 2$, within-plate alkali basalts and within-plate tholeiites; $B$, E-type mid-ocean ridge basalt (MORB); $C$, within-plate tholeiites and volcanic-arc basalts; $D, N-M O R B$ and volcanic arc basalts.

with negative Eu anomalies ( 0.56-0.59), but sample $\mathrm{B} 8$ has an almost flat REE pattern $\left(\mathrm{La}_{\mathrm{CN}} / \mathrm{Sm}_{\mathrm{CN}}\right.$ $=1.2$ ). The lavas are depleted in $\mathrm{Ba}, \mathrm{Nb}, \mathrm{Sr}, \mathrm{P}$, and $\mathrm{Ti}$ in the primitive mantle-normalized multielement diagram, while sample B8 shows $\mathrm{Hf}$ and $\mathrm{Zr}$ enrichments relative to LREEs and a positive $\mathrm{Sr}$ anomaly.

\section{Tracking the Sources}

Late Cambrian-Early Ordovician Volcanism. Because of their very low Mg\# values (20-14) and low $\mathrm{Ni}(\sim 45 \mathrm{ppm})$ and Cr contents ( 147 ppm), the Early Ordovician subalkali-basalts cannot be considered as primitive melts.

In the Early Ordovician volcanites, the $\mathrm{Nb} / \mathrm{Ta}$ ratio approaches 11, representative of crustalderived magmas (Green 1995). Overall, the patterns in figure 6 compare favorably with the middle crust from rifted continental margins (Rudnick and Fountain 1995). The high Th/Ta (11.5) and $\mathrm{La} / \mathrm{Nb}$ (3.39) values suggest a significant contamination by the upper continental crust rather than melting at middle-crustal levels, although this possibility cannot be ruled out entirely. However, the $\mathrm{Zr}-\mathrm{Nb}-\mathrm{Y}$ relationships indicate an enriched mantle source, although compositions with $\mathrm{CaO}+\mathrm{MgO}$ exceeding $12-20 \mathrm{wt} \%$ are to be considered with caution in the discriminant diagram of Meschede (1986; fig. 7).

The $\mathrm{Nb}$ negative anomaly, typical of subalkalic basalts in multielement diagrams (fig. 8), is considered to indicate subduction-related magmas (e.g., Pearce 1983), but it is also found in many continental flood basalts. The intermediate compositions (dacite, trachyandesite, and trachyte) have lower contents of $\mathrm{Ta}$ and $\mathrm{Nb}$, corresponding to contamination by-or anatexis in-the middlelower continental crust, where their abundances are lower than in upper crust and MORB (Weaver and Tarney 1984). High-silica rocks reveal LILE, Ta, and $\mathrm{Nb}$ enrichment (relative to HFSEs) in the ocean ridge granite-normalized multielement diagram (fig. $8 A$ ), and this is probably evidence of contamination in the upper crust. The $\mathrm{Th} / \mathrm{Ta}$ ratios in the felsic volcanics are generally lower than those in magmas from active continental margins (Gorton and Schandl 2000), and there is a considerable overlap with the within-plate volcanic zones field (fig. 9). 


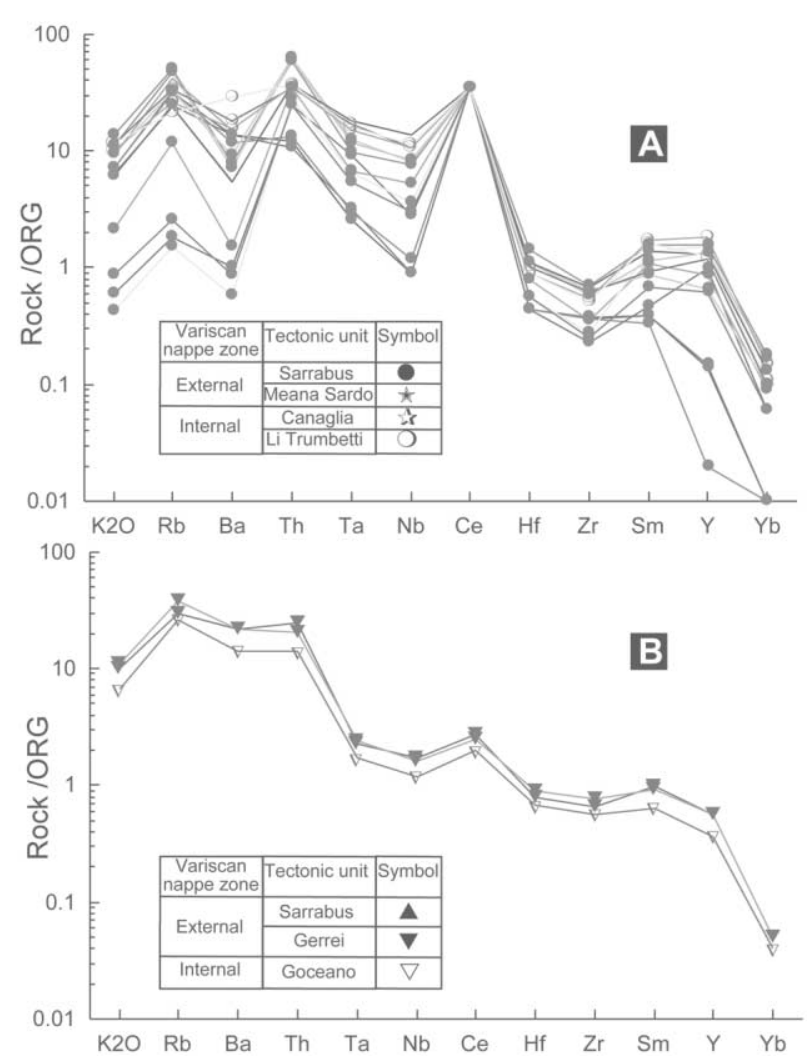

Figure 8. Multielement diagrams normalized to ocean ridge granites (Pearce et al. 1984) for felsic volcanic rocks of Early Ordovician $(A)$ and Middle Ordovician $(B)$ ages.

The strong HREE depletion and high values of $\mathrm{Ce} / \mathrm{Yb}$ and $\mathrm{Nb} / \mathrm{Y}$ in the trachyandesitic pyroclastic rocks and trachyte lava are consistent with small melt fractions and/or a melt fraction in equilibrium with a garnet residuum, possibly derived from a lower-crustal source.

Middle Ordovician Volcanism. The Middle Ordovician volcanic rocks in both the internal and external Variscan tectonic units consist of intermediate to fractionated rhyolitic compositions. The andesites are characterized by higher $\mathrm{Mg \#}$ values and lower $\mathrm{Ni}$ and $\mathrm{Cr}$ contents than the Early Ordovician subalkalic basalts, consistent with a subalkalic calc-alkalic affinity. HFSE (La, Ce, Hf, Th, $\mathrm{Zr}$, and $\mathrm{Sm}$ ) enrichments are evident, when compared with the primitive mantle normalization, and this confirms a crustal contribution; however, although LILEs $(\mathrm{Rb}, \mathrm{K})$ are generally enriched, they can also be affected by secondary mobilizations. Most significantly, the Th/Ta and Zr-Nb-Y relationships within the Middle Ordovician effusives are indicative of arc volcanic rocks and, in particular, with arc rocks from an active continental margin (figs. 7, 9).
Upper Ordovician-Silurian Volcanism. The alkali basalts have low $\mathrm{Th} / \mathrm{Ta}$ ratios in the range 1-2 and $\mathrm{Ta} / \mathrm{Yb}$ ratios that are $<2$, in the field of within-plate volcanism. $\mathrm{La} / \mathrm{Nb}$ values that are $<1$ in primitive mantle-normalized within-plate basalts compositions have been interpreted as related to (1) an "orogenic" component, possibly a hydrous metasomatized mantle that preserved a record of older subduction events (Cabanis and Thieblemont 1988; Cabanis et al. 1990), or (2) the involvement of lower continental crust (Innocent et al. 1994) or some segments of the continental lithospheric mantle (Hooper and Hawkesworth 1993, and references within) in the mantle source.

Sr-Nd Isotopic Compositions. The positive $\varepsilon \mathrm{Nd}_{490 \mathrm{Ma}}$ values of Early Ordovician rhyolitic ignimbrites $(+1.15$ to +2.42$)$ signify that their precursors, with a crustal residence age of $\sim 1 \mathrm{Ga}\left(T_{\mathrm{DM}}\right)$, were derived from a long-term depleted mantle source.

The high radiogenic ${ }^{87} \mathrm{Sr}$ content $\left({ }^{87} \mathrm{Sr} /{ }^{86} \mathrm{Sr}_{490 \mathrm{Ma}}=\right.$ 0.71169 ) and the $\mathrm{Nd}$ isotope fingerprint for one Early Ordovician dacite lava (corresponding to an $\varepsilon \mathrm{Nd}_{490 \mathrm{Ma}}$ value of -6.54$)$ provide evidence for a role of lower crust in the source region, alternatively (1) a single stage mantle melt and fractional crystallization or (2) a mixing of primary basaltic melts issued from the mantle with some amounts of remelted material either from the crust or at earlier phases of magmatism. The high radiogenic ${ }^{87} \mathrm{Sr}$ content could imply a time-integrated LREE-enriched source, consistent with the anatexis of a metasedimentary component. The latter could be a Cadomian basement, which is well known in the hinterland of Corsica (Barca et al. 1996; Rossi et al. 2009), felsic granulites from the European Variscides (Liew and Hofmann 1988), or crustal contamination of mantle-derived magmas (fig. A2, available in the online edition or from the Journal of Geology office). In effect, the data match the isotopic data reported by Pin and Marini (1993) for coeval felsic volcanics from the southern Massif Central (France), where $\varepsilon \mathrm{Nd}_{480 \mathrm{Ma}}$ lies between -3.5 and -6.0, and ${ }^{87} \mathrm{Sr} /{ }^{86} \mathrm{Sr}_{480 \mathrm{Ma}}$ is in the range 0.70889 to 0.70901 (fig. 10).

The Sr and Nd isotopic compositions of Middle Ordovician andesite lava and dacitic tuff are consistent with a mantle source that is less depleted than the source of the Early Ordovician rhyolitic ignimbrites $\left(\varepsilon \mathrm{Nd}_{465 \mathrm{Ma}}=-3.03\right.$ to -5.75 ; ${ }^{87} \mathrm{Sr} /{ }^{86} \mathrm{Sr}_{465 \mathrm{Ma}}=0.70931-0.71071$; fig. A2). The data make a good match with the compositions of the Lodè and Golfo Aranci orthogneisses $\left(\varepsilon \mathrm{Nd}_{465 \mathrm{Ma}}=\right.$ -4.32 to -5.11 ; Di Vincenzo et al. 1996), though with a scatter for ${ }^{87} \mathrm{Sr} /{ }^{86} \mathrm{Sr}\left({ }^{87} \mathrm{Sr} /{ }^{86} \mathrm{Sr}_{465 \mathrm{Ma}}=0.69965-\right.$ 


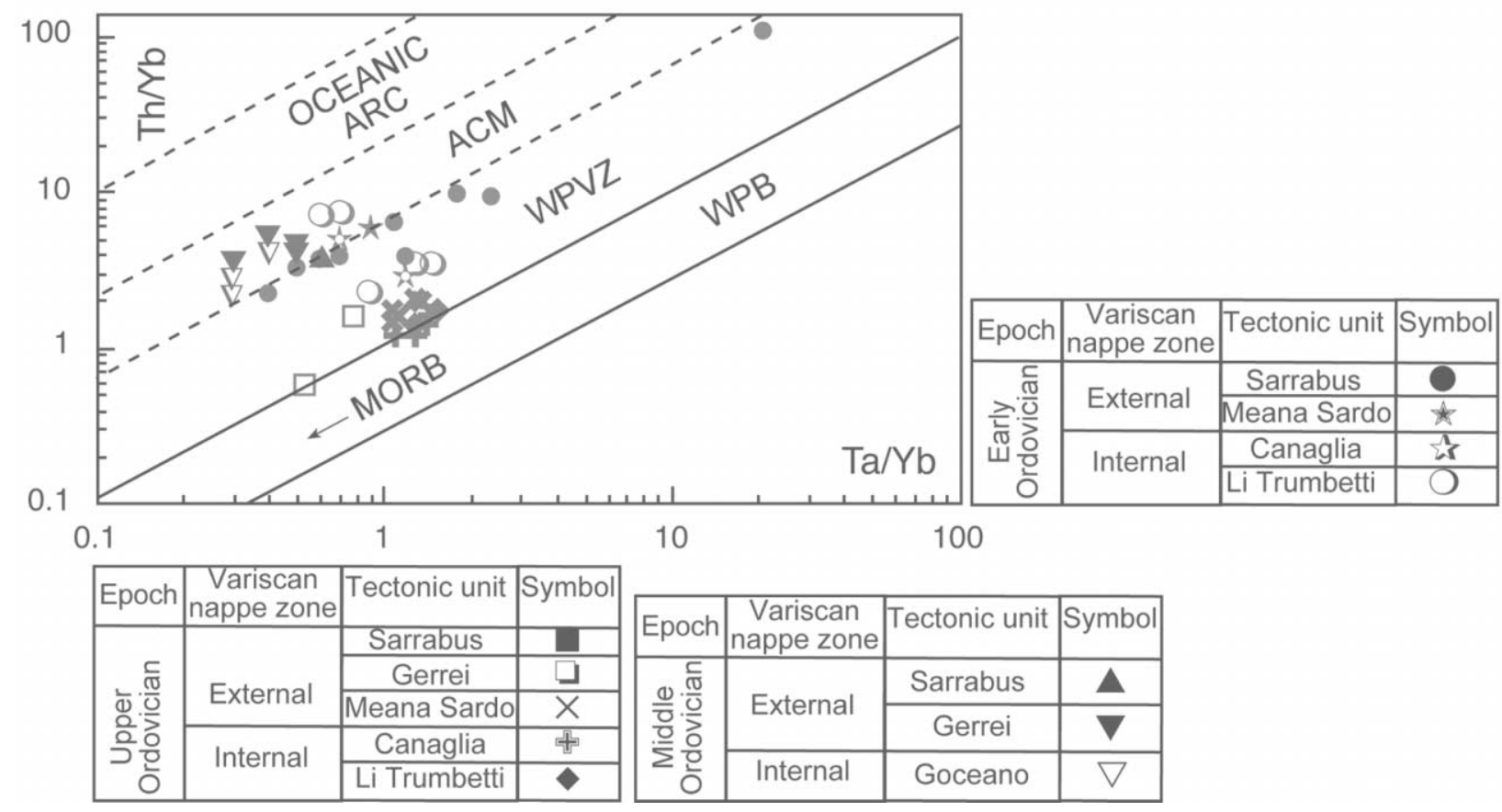

Figure 9. $\mathrm{Th} / \mathrm{Yb}-\mathrm{Ta} / \mathrm{Yb}$ diagram (Gorton and Schandl 2000) for felsic volcanics from Sardinia. $\mathrm{ACM}$, active continental margin; WPVZ, within-plate volcanic zone; WPB, within-plate basalts.

0.70839 ). The negative $\mathrm{Nd}$ values suggest the melting of a sub-arc mantle that was variably enriched by the recycling of continental material, possibly during subduction events that predate the Middle Ordovician arc.

Crustal residency ages, indicated by $\mathrm{Nd}$ model age data, suggest that (1) this continental block underwent orogenesis at 1.0 and $1.4-1.6 \mathrm{Ga}$, incorporating crustal components from different source areas, or (2) there was a juxtaposition of Mesoproterozoic crust above a Neoproterozoic subcontinental mantle lithosphere (Murphy et al. 2008).

The similar $\mathrm{Nd}$ isotopic compositions of the Early and Middle Ordovician dacite lavas should be considered as an inherited feature that resulted from the repeated extraction of melts from a common basement source ( $\left.T_{\mathrm{DM}}=1.4-1.6 \mathrm{Ga}\right)$. This interpretation is supported by the population of Neoproterozoic inherited zircons, which is conspicuous in the Early Ordovician felsic volcanic rocks but less so in the Middle Ordovician andesites (Oggiano et al. 2010).

According to the ${ }^{143} \mathrm{Nd} /{ }^{144} \mathrm{Nd}$ vs. ${ }^{147} \mathrm{Sm} /{ }^{144} \mathrm{Nd}$ correlation, the slope of the best-fit line of the eight Upper Ordovician alkali basalt samples corresponds to $440 \mathrm{Ma}$, though with a large scatter (MSWD $=10.1$ ), and an initial ${ }^{143} \mathrm{Nd} /{ }^{144} \mathrm{Nd}$ ratio of $0.51221 \pm 0.00052$. In spite of the uncertainty, the closeness of this value to $440 \pm 1.7 \mathrm{Ma}$ suggests that the Sm-Nd isotope system has not been deeply perturbed since the crystallization of the magmas.

The $\varepsilon \mathrm{Nd}$ values for the alkali basalts (calculated for $t=440 \mathrm{Ma}$ ) range from +1.60 to +4.14 , reflecting an origin in a depleted mantle source, while the ${ }^{87} \mathrm{Sr} /{ }^{86} \mathrm{Sr}_{440 \mathrm{Ma}}$ values vary from 0.70520 to 0.71321 (fig. A2). One very low ${ }^{87} \mathrm{Sr} /{ }^{86} \mathrm{Sr}$ value of 0.69434 (sample ORD32) is probably due to $\mathrm{Rb}$ and $\mathrm{Sr}$ mobilization during the Variscan metamorphic event. On the whole, the results are consistent with the $\mathrm{Nd}$ isotopic compositions of the $436 \pm 17-\mathrm{Ma}$ mafic sills from the Central Iberian Zone (Sm-Nd isochron age; López-Moro et al. 2007). The negative ${ }_{\varepsilon} \mathrm{Nd}_{440 \mathrm{Ma}}$ values of -4.76 and -4.62 for the trachyandesite pillow lavas, coupled with the high $\mathrm{Th} / \mathrm{Ta}$ values (3.4-6.8), indicate a less depleted mantle source, while the values of ${ }^{87} \mathrm{Sr} /{ }^{86} \mathrm{Sr}_{440 \mathrm{Ma}}(0.70511-$ 0.70694 ) and $\mathrm{Sm} / \mathrm{Nd}$ (up to 0.36) extend along the mantle array.

\section{Discussion}

According to von Raumer and Stampfli (2008), the northward dispersal of crustal blocks derived from the North Gondwana margin occurred between the Late Cambrian and Devonian under a variety of kinematic regimes, including local back-arc spread- 
ing, intracontinental rifting, and even the spreading of a mid-ocean ridge (e.g., in the Chamrousse area of the western Alps).

Late Cambrian-Early Ordovician. It is widely reported that Late Cambrian-Early Ordovician bimodal magmatism within terrigenous and carbonate shelf deposits is related to the diachronous northward rifting-to-drifting of microplates from the western (ca. $500 \mathrm{Ma}$, Avalonian terranes) to the eastern Gondwana margins (ca. $460 \mathrm{Ma}$, Hun and Galatian terranes; e.g., Carmignani et al. 1994; Stampfli et al. 2002; Sánchez-García et al. 2003; Etxebarria et al. 2006; Murphy et al. 2006; Montero et al. 2007; Pin et al. 2007; Castiñeiras et al. 2011; Chichorro et al. 2008).

In the French Massif Central, the Late CambrianLower Ordovician volcanic rocks are the protoliths of the leptynite-amphibolite complexes (487-478 $\mathrm{Ma}$; Pin and Lancelot 1982). In the Bohemian massif, Pin et al. (2007) reported a 500-Ma bimodal suite that is referred to as anorogenic, supposedly related to extension along the margin of North Gondwana, although no oceanic lithosphere was generated. In Iberia, rhyolitic to dacitic tuffs and later alkaline basaltic lava flows with ages of 515-490 Ma (Ossa Morena Zone and Iberian Chain; Álvaro et al. 2008; Chichorro et al. 2008) match both the ages and the signatures of the "pre-Sardic phase" volcanic rocks of the Sardinia nappe zone. Because of their subalkaline to alkaline signatures and the association with terrigenous sedimentation, an ensialic rift environment preliminary to oceanization has been inferred (Sánchez-García et al. 2003; Etxebarria et al. 2006; Chichorro et al. 2008). Díez Montes et al. (2010) referred the Ollo de Sapo volcanic rocks to an incipient rift that evolved by the necking and crustal-scale boudinage of the wide passive margin of North Gondwana. Mafic magmas that intrude or underplate the lower crust were proposed as heat sources for crustal melting.

The occurrence of pre-Sardic Late CambrianEarly Ordovician volcanic rocks in Sardinia suggests the following possible scenarios: (1) a continental volcanic arc that lasted from the Upper Cambrian to the Middle Ordovician and that can be related to the subduction of a proto-Tethyan oceanic crust beneath the northern peripheries of Gondwana, (2) a back-arc region that was subjected to extension (e.g., Iberia; Fernández et al. 2008), (3) an aborted rifting stage during the Late Cambrian, and (4) the onset of a passive volcanic margin (e.g., the Cameroon line; Fitton 1987) that preceded the calc-alkaline, subduction-related, Middle Ordovician suite. Felsic and mafic volcanic activities high- light an ongoing extension along the northern marginal areas of Gondwana during the Early Ordovician.

There exists uncertainty in terms of correlating the stratigraphic and timing relationships of volcanic events in the pre-Sardic succession of Sardinia with the Armorican (Ballèvre et al. 2009) or Iberian domains (López-Guijarro et al. 2008). Overall, the different domains of Late Cambrian-Early Ordovician volcanism seem to retain distinctive geochemical features.

Taken together, the geochemical and isotopic data for the felsic volcanics suggest (1) an origin by anatexis of a crustal source, probably as small melt fractions and/or with a garnet control (i.e., thick lithosphere). However, in the alternative of (2) remelting in the crust and mixing, the melt fraction can vary over a wide range, and metamorphic garnet can occur in the crustal source region without need of an unusual thick lithosphere. Afterward, the transition from early felsic to later more mafic magmatism points to the gradual opening of the system. The middle-crustal signature of the subalkalic basalts could be produced by crustal melting fed by the intrusion of small batches of hot magma from the mantle, probably linked to the onset of a volcanic passive margin.

The structural style of the Cambro-Ordovician rift at upper-crustal and syn-rift sedimentary levels as well as the geochemical signature of the volcanic rocks suggests the lithosphere was relatively thick and cold at depth. However, the volumes of the intrusive and effusive volcanic rocks are much smaller than those found in present-day volcanic passive margins (e.g., Tsikalas et al. 2008; Hirsch et al. 2009; Voss et al. 2009). Therefore, the overall tectonic setting of the Cambro-Ordovician rift in Sardinia better fits the features of an aborted rift. In general, it seems that a diversity of geological settings existed along the North Gondwana margin at the time of the Cambrian-Ordovician boundary.

Mid-Ordovician. The conspicuous Mid-Ordovician Andean-type arc volcanism, which marks the onset of subduction beneath the southern Rheic margin after the Lower Ordovician (Carmignani et al. 1994), ceased in the Upper Ordovician. This subalkalic calc-alkalic suite developed after the Sardic phase, which is widespread over all the external nappes but absent in the internal nappes and in the foreland, can be bracketed stratigraphically between the Floian and the Katian. In fact, in the external nappes, the volcanism formerly ascribed to the Middle Ordovician cycle has been recently reassessed as Early Ordovician $(486 \pm 1.2$ and 

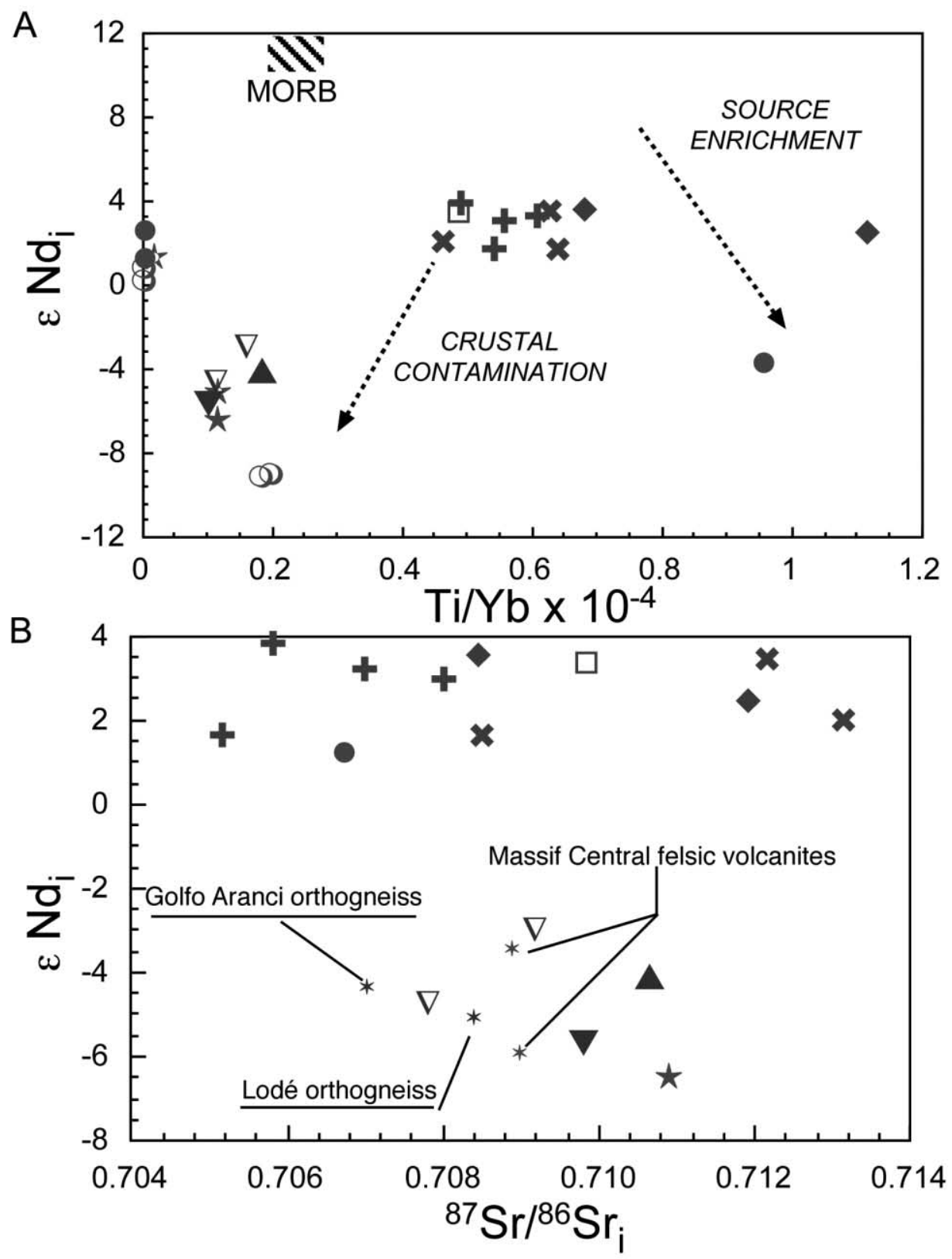

\begin{tabular}{|c|c|c|c|c|c|c|c|}
\hline Epoch & \begin{tabular}{|c|} 
Variscan \\
nappe zone
\end{tabular} & Tectonic unit & Symbol & Epoch & \begin{tabular}{|c|} 
Variscan \\
nappe zone
\end{tabular} & Tectonic unit & Symbol \\
\hline \multirow{3}{*}{ 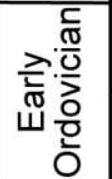 } & \multirow{2}{*}{ External } & Sarrabus & & \multirow{3}{*}{ 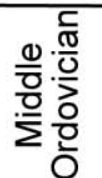 } & \multirow[b]{2}{*}{ External } & Sarrabus & $\Delta$ \\
\hline & & Meana Sardo & $\frac{\hbar}{t}$ & & & Gerrei & \\
\hline & Internal & Li Trumbetti & $\frac{a}{O}$ & & Internal & Goceano & $\nabla$ \\
\hline
\end{tabular}

\begin{tabular}{|c|c|c|c|}
\hline Epoch & \begin{tabular}{|c} 
Variscan \\
nappe zone
\end{tabular} & Tectonic unit & Symbol \\
\hline \multirow{5}{*}{ 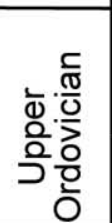 } & \multirow{3}{*}{ External } & Sarrabus & \\
\hline & & Gerrei & $\bar{\square}$ \\
\hline & & Meana Sardo & X \\
\hline & \multirow{2}{*}{ Internal } & Canaglia & t \\
\hline & & Li Trumbetti & 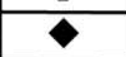 \\
\hline
\end{tabular}


$479.9 \pm 2.1 \mathrm{Ma}$; Oggiano et al. 2010). In the internal nappes, volcanic rocks may possibly have been the protoliths of the migmatites, as inferred by Cruciani et al. (2001, 2008). The lack of Middle Ordovician volcanic rocks in the foreland suggests that the this region acted as an Andean-type backarc, which experienced only continental clastic sedimentation and which was subjected to constant uplift and renewal of relief as a result of faulting (Martini et al. 1992). The distribution of Middle Ordovician volcanic products is restricted to the external nappes, where mostly felsic and intermediate products occur.

Late Ordovician. Late Ordovician-Early Silurian mafic lavas, sills (Lehman 1975; Ricci and Sabatini 1978; Oggiano and Mameli 2006), and their feeder dykes (Di Pisa et al. 1992) have been described and dated (Oggiano et al. 2010) in the Sardinia basement. On the regional scale, Silurian mafic sills have been documented from the Central Iberian Zone $(436 \pm 17 \mathrm{Ma}$, Sm-Nd isochron; López-Moro et al. 2007). Only a few works have focused on this volcanism in Sardinia, and Di Pisa et al. (1992) have described the field relationships, petrography, and elemental geochemistry. These rocks were inferred to be of Lower Carboniferous age (Di Pisa et al. 1992). The bulk compositions of the mafic lavas, sills, and dykes are homogeneous, thus supporting the concept of a common volcanic event that overprinted the internal and external nappes at the time of the Ordovician-Silurian boundary. By analogy with modern equivalents of postorogenic volcanism, an origin by partial melting at minimum temperatures could be envisaged.

However, the geochemical data for the Upper Ordovician alkalic suite in Sardinia suggest a continental rift geodynamic setting, most probably an early phase of the major rifting event that led to expansion of the Paleotethys. Nevertheless, a reconstruction along the northeastern Gondwana margin (von Raumer and Stampfli 2008; Rossi et al. 2009) at this time points to back-arc spreading. We consider that the radiometric, geochemical, and isotopic data for contiguous terranes along the North Gondwana margin suggest a variety of geodynamic settings rather than one continuous extensional regime related to the opening of the Rheic or the Rheic and Paleotethys oceans in this region during the Ordovician and Silurian.

\section{Concluding Remarks}

The new data presented here on pre-Variscan volcanic rocks of Sardinia improve our understanding of the geodynamic setting of the North Gondwana margin before the Variscan collision within the Southern Variscan Realm. In fact, despite good exposures, the Sardinian segment of the Variscan chain has barely been considered in reconstructions of the Variscan orogeny since the first attempts of Carmignani et al. (1994). Broadly speaking, previous reconstructions of the South Variscan Branch have envisaged a complex pattern of local back-arc basins or intracontinental rifts during the Early Cambrian, followed by Upper Cambrian-Early Ordovician closure (von Raumer and Stampfli 2008). However, these scenarios do not match the geological evolution of Sardinia, as indicated by its volcanic activity. In fact, the following are the main findings indicated by the geochemistry of the volcanic rocks and their spatial and temporal relationships (fig. 11):

1. In Sardinia, the mildly alkaline, pre-Sardic volcanic activity represents an intracontinental extensional setting such as a rift. This rifting is coeval with the breakup that led to the opening of the Rheic Ocean and the drift of Avalonia to the west of Sardinia crust, which did not propagate to this part of the North Gondwana margin. There is no evidence in the Late Cambrian-Early Ordovician volcanic rocks for the convergence that started later in the Middle Ordovician.

2. During the Middle Ordovician, the Sardinian crust experienced arc volcanism that is well constrained by geochronology, geochemistry, and field evidence. This volcanism differed from the largescale, extension-related volcanic activity (reported elsewhere from North Gondwana) that led to the opening of the Paleotethys at the same time as the eastern Gondwana margin experienced the start of the drift of the future Hun superterrane.

3. The Upper Ordovician-Early Silurian metabasalts show unquestionable alkaline signatures that constrain the onset of an important period of

Figure 10. $A, \varepsilon \mathrm{Ndi}$ versus $\mathrm{Ti} / \mathrm{Yb} \times 10^{-4}$ and MORB field, source enrichment, and crustal contamination vectors. $B$, $\varepsilon N d i$ versus ${ }^{87} \mathrm{Sr} /{ }^{86} \mathrm{Sr}_{\mathrm{i}}$. For comparison with Early Ordovician volcanism, felsic volcanics from the southern Massif Central (Pin and Marini 1993) are reported. Lodè and Golfo Aranci orthogneisses (Di Vincenzo et al. 1996) are reported to be similar to the Middle Ordovician volcanic rocks. 


\section{CAMBRIAN - EARLY ORDOVICIAN}

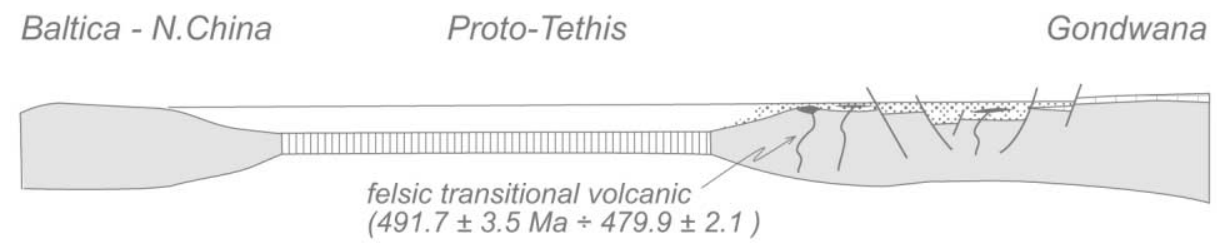

MIDDLE - UPPER ORDOVICIAN

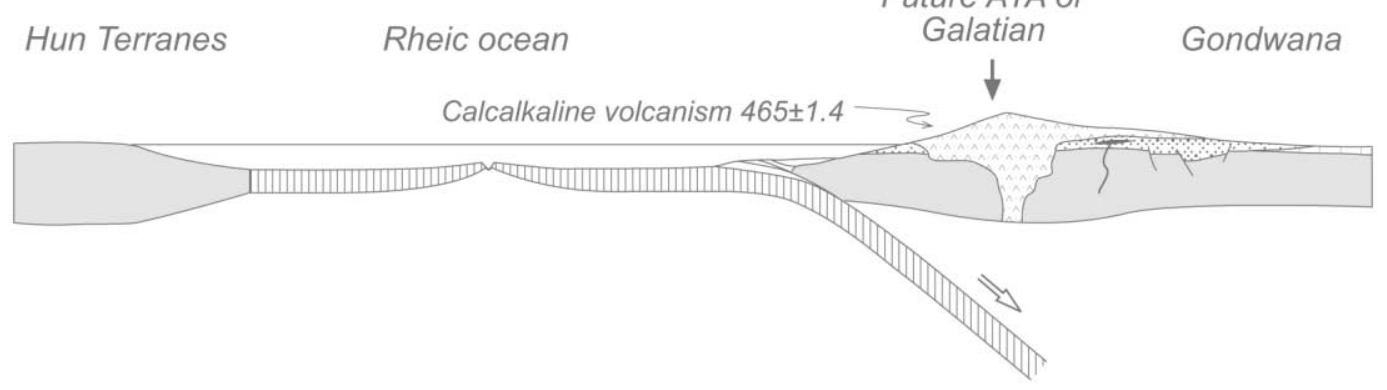

LATE ORDOVICIAN - EARLY SILURIAN

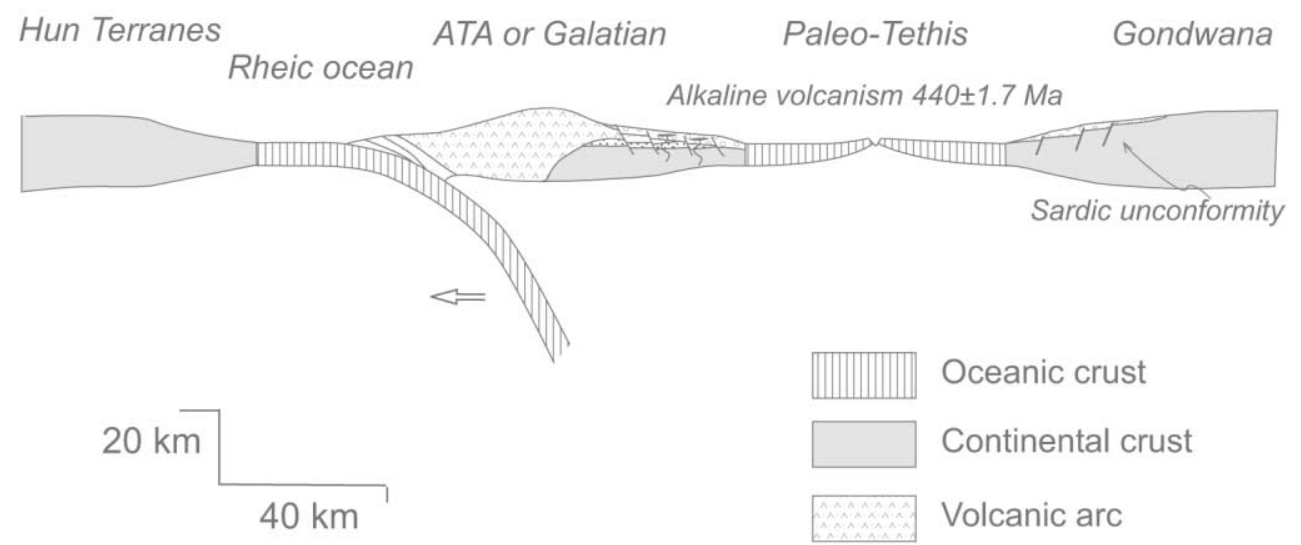

Figure 11. Schematic palinspastic reconstruction of the possible evolution of northern Gondwana between the early and middle Paleozoic, as inferred from geochemical and geological evidence in Sardinia.

rift dynamics along the North Gondwana margin. If this rift had led to the detachment of the Armorica Terrane Assemblage or Galatian from North Gondwana, the onset of the drift of terranes should have occurred in the Early Silurian, possibly driven by slab retreat after an aborted rifting episode at the Late Cambrian-Early Ordovician boundary, and after the onset of oceanic (Rheic) subduction beneath the North Gondwana margin in the Middle Ordovician (fig. 11). It has yet to be established whether the expanding oceanic basin and consequent latitudinal gap between the shelves of Gondwana and the Armorica Terrane Assemblage were wide enough to support faunal and/or climatic differentiation. Assuming the average spreading rates of present-day back-arc basins and oceanic rifts, North Gondwana and its detached terranes-at least those involved in the Southern Variscan Realm-display similar climatic environments and must be set at high latitudes until the Early Silurian. Although paleomagnetic data are scant and debated when available (Robardet 2003), the Ordovician-Silurian diamictite of glacio-marine origin of Sardinia (Oggiano and Mameli 2006) provide the lithostratigraphic evidence of eustatic emergence, fit in well with the glacio-eustatic record of 
North Gondwana (Loi et al. 2010), and are comparable with the coeval glacial deposits of Brittany (Piçarra et al. 2002), Corsica (Barca et al. 1996), Cantabria (Gutiérrez-Marco et al. 2010), and Thuringia (Erdtmann 1991). All these crustal sectors are related to the Armorica Terrane Assemblage, which detached from Gondwana and were accreted on Laurussia.

\section{A C K N O W L E D G M E N T S}

This research was carried out with the aid of PRIN 2004 (L. Cortesogno, G. Oggiano), PRIN 2008 (G. Oggiano, L. Gaggero), Ateneo 2006 (University of Genoa), a grant to L. Gaggero, PRIN 2007, and ex $60 \%$ University of Cagliari grants to A. Funedda. We thank F. Slejko and R. Petrini for help with acquiring isotope data.

\section{R E FER E N C E S C I T E D}

Álvaro, J. J.; Ezzouhairi, H.; Ribeiro, M. L.; Ramos, J. F.; and Solá, A. R. 2008. Early Ordovician volcanism in the Iberian Chains (NE Spain) and its influence on the preservation of shell concentrations. Bull. Soc. Geol. Fr. 179:569-581.

Ballèvre, M.; Bosse, V.; Ducassou, C.; and Pitra, P. 2009. Palaeozoic history of the Armorican Massif: models for the tectonic evolution of the suture zones. C. R. Geosci. 341:174-201.

Barca, S.; Carmignani, L.; Oggiano, G.; Pertusati, P. C.; and Salvatori, I. 1996. Carta Geologica della Sardegna. In Carmignani, L., ed. Servizio Geologico Nazionale. Litografia Artistica Cartografica, Firenze.

Beccaluva, L.; Leone, F.; Maccioni, L.; and Macciotta, G. 1981. Petrology and tectonic setting of the Palaeozoic basic rocks from Iglesiente-Sulcis (Sardinia, Italy). Neues Jahrb. Mineral. Abh. 140:184-201.

Bosellini, A., and Ogniben, G. 1968. Ricopriment ercinici nella Sardegna centrale. Ann. Univ. Ferrara 1:1-15.

Cabanis, B.; Cochemé, J. J.; Vellutini, P. J.; Joron, J. L.; and Treuil, M. 1990. Post-collisional Permian volcanism in northwestern Corsica: an assessment based on mineralogy and trace-element geochemistry. J. Volcanol. Geotherm. Res. 44:51-67.

Cabanis, B., and Thieblemont, D. 1988. La discrimination des tholeiites continentales et des basaltes arrière-arc: proposition d'un nouveau diagramme, le triangle Th-Tbx3-Tax2. Bull. Soc. Geol. Fr. 4:927-935.

Calvino, F. 1972. Note illustrative alla carta geologica d'Italia, foglio 227-Muravera, p. 60. Servizio Geologico d'Italia, Roma.

Cappelli, B.; Carmignani, L.; Castorina, F.; Di Pisa, A.; Oggiano, G.; and Petrini, R. 1992. A Hercynian suture zone in Sardinia: geological and geochemical evidence. Geodin. Acta 5:101-11.

Carmignani, L.; Cocozza, T.; Minzoni, N.; Pertusati, P. C.; and Ricci, C. A. 1979. É la Corsica il retropaese della catena ercinica della Sardegna? Mem. Soc. Geol. Ital. 20:45-55.

Carmignani, L.; Carosi, R.; Di Pisa, A.; Gattiglio, M.; Musumeci, G.; Oggiano, G.; and Pertusati, P. C. 1994. The Hercynian chain in Sardinia. Geodin. Acta 7:3147.

Carmignani, L.; Conti, P.; Barca, S.; Cerbai, N.; Eltrudis, A.; Funedda, A.; Oggiano, G.; et al. 2001. Note illustrative del foglio 549-Muravera. Roma, Memorie
Descrittive Della Carta Geologica d'Italia, scale 1 : 50,000, $140 \mathrm{p}$.

Casas, J. M.; Castiñeiras, P.; Navidad, M.; Liesa, M.; and Carreras, J. 2010. New insights into the Late Ordovician magmatism in the Eastern Pyrenees: U-Pb SHRIMP zircon data from the Canigó massif. Gondwana Res. 17:317-324.

Casini, L.; Funedda, A.; and Oggiano, G. 2010. A balanced foreland-hinterland deformation model for the Southern Variscan belt of Sardinia, Italy. Geol. J. 45:634649.

Castiñeiras, P.; Navidad, M.; Casas, J. M.; Liesa, M.; and Carreras, J. 2011. Petrogenesis of Ordovician magmatism in the Pyrenees (Albera and Canigó Massifs) determined on the basis of zircon minor and trace element composition. J. Geol. 119:521-534.

Chichorro, M.; Pereira, M. F.; Díaz-Azpiroz, M.; Williams, I. S.; Fernández, C.; Pin, C.; and Silva, J. B. 2008. Cambrian ensialic rift-related magmatism in the Ossa-Morena Zone (Évora-Aracena metamorphic belt, SW Iberian Massif): Sm-Nd isotopes and SHRIMP zircon U-Th-Pb geochronology. Tectonophysics 461:91113.

Cocozza, T. 1979. The Cambrian of Sardinia. Mem. Soc. Geol. Ital. 20:163-187.

Cortesogno, L.; Gaggero, L.; Oggiano, G.; and Paquette, J. L. 2004. Different tectono-thermal evolutionary paths in eclogitic rocks from the axial zone of the Variscan chain in Sardinia (Italy) compared with the Ligurian Alps. Ofioliti 29:125-144.

Cruciani, G.; Franceschelli, M.; Caredda, A. M.; and Carcangiu, G. 2001. Anatexis in the Hercynian basement of NE Sardinia, Italy: a case study of the migmatite of Porto Ottiolu. Mineral. Petrol. 71:195-233.

Cruciani, G.; Franceschelli, M.; Elter, F. M.; Puxeddu, M.; and Utzeri, D. 2008. Petrogenesis of Al-silicate-bearing trondhjemitic migmatites from NE Sardinia, Italy. Lithos 102:554-574.

Delaperrière, E., and Lancelot, J. 1989. Datation U-Pb sur zircon de l'orthogneiss du Capo Spartivento (Sardaigne, Italie), nouveau témoin d'un magmatisme alcalin ordovicien dans le Sud de l'Europe. C. R. Acad. Sci. 309:835-842.

Di Pisa, A., and Oggiano, G. 1984. Segnalazione di un orizzonte carbonatico nella Nurra paleozoica e suo significato stratigrafico nelle successioni dell'Ercinico 
sardo. Atti Soc. Toscana Sci. Nat. Mem. Ser. A 91: 141-154.

Di Pisa, A.; Gattiglio, M.; and Oggiano, G. 1992. PreHercynian magmatic activity in the nappe zone (internal and external) of Sardinia: evidence of two within plate basaltic cycles. In Carmignani L., and Sassi, F. P., eds. Contribution to the geology of Italy with special regard to the Palaeozoic basement: a volume dedicated to Tommaso Cocozza. IGCP project 276, newsletter 5, p. 33-44.

Di Vincenzo, G.; Andriessen, P. A. M.; and Ghezzo, C. 1996. Evidence of two different components in a Hercynian peraluminous cordierite-bearing granite: the San Basilio intrusion (central Sardinia, Italy). J. Petrol. 37:1175-1206.

Díez Montes, A.; Martínez Catalán, J. R.; and Bellido Mulas, F. 2010. Role of the Ollo de Sapo massive felsic volcanism of NW Iberia in the Early Ordovician dynamics of northern Gondwana. Gondwana Res. 17: 363-376.

Erdtmann, B. D. 1991. The post-Cadomian Early Palaeozoic tectono-stratigraphy of Germany (attempt to an analytical review). Ann. Soc. Geol. Belg. 114:19-43.

Etxebarria, M.; Chalot-Prat, F.; Apraiz, A.; and Ehuiluz, L. 2006. Birth of a volcanic passive margin in Cambrian time: rift paleogeography of the Ossa-Morena Zone, SW Spain. Precambrian Res. 147:366-386.

Fernández, C.; Becchio, R.; Castro, A.; Viramonte, J. M.; Moreno-Ventas, I.; and Corretgé, L. G. 2008. Massive generation of atypical ferrosilicic magmas along the Gondwana active margin: implications for cold plumes and back-arc magma generation. Gondwana Res. 14:451-473.

Fitton, J. G. 1987. The Cameroon line, West Africa: a comparison between oceanic and continental alkaline volcanism. In Fitton, J. G., and Upton, B. G. J., eds. Alkaline igneous rocks. Geol. Soc. Am. Spec. Publ. 30: 273-291.

Franceschelli, M.; Puxeddu, M.; Cruciani, G.; and Utzeri, D. 2007. Metabasites with eclogite facies relics from Variscides in Sardinia, Italy: a review. Int. J. Earth Sci. 96:795-815.

Funedda, A. 2000. Nota preliminare su un intervallo sedimentario all'interno del ciclo vulcanico calcalcalino dell'Ordoviciano medio della Sardegna SE: la Formazione di Su Muzzioni. Atti Soc. Sarda Sci. Nat. 32:2939.

Galassi, R., and Gandin, A. 1992. New structural data and their bearing on the Cambrian stratigraphy of the Iglesiente region (SW Sardinia, Italy). C. R. Acad. Sci. 314:93-100.

Ghienne, J.-F.; Bartier, D.; Leone, F.; and Loi, A. 2000. Caractérisation des horizons manganésifères de l'Ordovicien supérieur de Sardaigne: relation avec la glaciation fini-ordovicienne. C. R. Acad. Sci. 331:257264.

Giacomini, F.; Bomparola, R. M.; and Ghezzo, C. 2005. Petrology and geochronology of metabasites with eclogite facies relics from NE Sardinia: constraints for the Palaeozoic evolution of Southern Europe. Lithos 82:221-248.

Gorton, M. P., and Schandl, E. S. 2000. From continents to island arcs: a geochemical index of tectonic setting for arc-related and within-plate felsic to intermediate volcanic rocks. Can. Mineral. 38:1065-1073.

Green, T. H. 1995. Significance of $\mathrm{Nb} / \mathrm{Ta}$ as an indicator of geochemical processes in the crust-mantle system. Chem. Geol. 120:347-359.

Gutiérrez-Marco, J. C.; Ghienne, J. F.; Bernardez, E.; and Hacar, M. P. 2010. Did the Late Ordovician African ice sheet reach Europe? Geology 38:279-282.

Hanson, G. N. 1980. Rare earth elements in petrogenetic studies of igneous systems. Annu. Rev. Earth Planet. Sci. 8:371-406.

Hirsch, K. K.; Bauer, K.; and Scheck-Wenderoth, M. 2009. Deep structure of the western South African passive margin: results of a combined approach of seismic, gravity and isostatic investigations. Tectonophysics 470:57-70.

Hooper, P. R., and Hawkesworth, C. J. 1993. Isotopic and geochemical constraints on the origin and evolution of the Columbia River Basalt. J. Petrol. 34:1203-1246.

Icenhower, J., and London, D. 1996. Experimental partitioning of $\mathrm{Rb}, \mathrm{Cs}, \mathrm{Sr}$, and $\mathrm{Ba}$ between alkali feldspar and peraluminous melt. Am. Mineral. 81:719-734.

Innocent, C.; Briqueu, L.; and Cabanis, B. 1994. Sr-Nd isotope and trace element geochemistry of late Variscan volcanism in the Pyrenees: magmatism in postorogenic extension? Tectonophysics 238:161-181.

Keppie, J. D.; Dostal, J.; Miller, B. V.; Ramos-Arias, M. A.; Morales-Gámez, M.; Nance, R. D.; Murphy, J. B.; et al. 2008. Ordovician-earliest Silurian rift tholeiites in the Acatlán Complex, southern Mexico: evidence of rifting on the southern margin of the Rheic Ocean. Tectonophysics 461:130-156.

Lehman, B. 1975. Stratabound polymetallic and F-Ba deposits of the Sarrabus-Gerrei region, SE Sardinia. IV. Report: initial Variscan magmatism in SE Sardinia. Neues Jahrb. Geol. Palaeontol. Monatshefte 1975, 460-470.

Leone, F.; Hamman, W.; Laske, R.; Serpagli, E.; and Villas, E. 1991. Lithostratigraphic units and biostratigraphy of the post-Sardic Ordovician sequence in southwest Sardinia. Boll. Soc. Paleontol. Ital. 30:201-235.

Liew, T. C., and Hofmann, A. W. 1988. Precambrian crustal components, plutonic associations, plate environment of the Hercynian Fold Belt of central Europe: indications from a $\mathrm{Nd}$ and $\mathrm{Sr}$ isotopic study. Contrib. Mineral. Petrol. 98:129-138.

Linnemann, U.; Pereira, F.; Jeffries, T. E.; Drost, K.; and Gerdes, A. 2008. The Cadomian Orogeny and the opening of the Rheic Ocean: the diachrony of geotectonic processes constrained by LA-ICP-MS U-Pb zircon dating (Ossa-Morena and Saxo-Thuringian Zones, Iberian and Bohemian Massifs). Tectonophysics 461: 21-43.

Loi, A.; Ghienne, J.-F.; Dabard, M. P.; Paris, F.; Botquelen, A.; Christ, N.; Elaouad-Debbaj, Z.; et al. 2010. The Late Ordovician glacio-eustatic record from a high- 
latitude storm-dominated shelf succession: the Bou Ingarf section (Anti-Atlas, Southern Morocco). Palaeogeogr. Palaeoclimatol. Palaeoecol. 296:332-358.

López-Guijarro, R.; Armendáriz, M.; Quesada, C.; Fernández-Suárez, J.; Murphy, J. B.; Pin, C.; and Bellindo, F. 2008. Ediacaran-Palaeozoic tectonic evolution of the Ossa Morena and Central Iberian zones (SW Iberia) as revealed by $\mathrm{Sm}-\mathrm{Nd}$ isotope systematics. Tectonophysics 461:202-214.

López-Moro, F. J.; Murciego, A.; and López-Plaza, M. 2007. Silurian/Ordovician asymmetrical sill-like bodies from La Codosera syncline, W Spain: a case of tholeiitic partial melts emplaced in a single magma pulse and derived from a metasomatized mantle source. Lithos 96:567-590.

Ludwig, K. R. 1994. Analyst: a computer program for control of a thermal-ionization single-collector massspectrometer. U.S. Geol. Surv. Open File Rep. 92-543.

Macdonald, R.; Bailey, D. K.; and Barberi, F. 1974. Recommendations for further studies on the peralkaline oversaturated volcanic rocks. Bull. Volcanol. 38:828860.

Martini, I. P.; Oggiano, G.; and Mazzei, R. 1992. Siliciclastic-carbonate sequences of Miocene grabens of Northern Sardinia, Western Mediterranea Sea. Sediment. Geol. 72:97-115.

Meschede, M. 1986. A method of discriminating between different types of mid-ocean ridge basalts and continental tholeiites with the $\mathrm{Nb}-\mathrm{Zr}-\mathrm{Y}$ diagram. Chem. Geol. 56:207-218.

Montero, P.; Bea, F.; Gonzalez-Lodiero, F.; Talavera, C.; and Whitehouse, M. J. 2007. Zircon ages of the metavolcanic rocks and metagranites of the Ollo de Sapo domain in central Spain: implications for the Neoproterozoic to Early Paleozoic evolution of Iberia. Geol. Mag. 144:963-976.

Murphy, J. B.; Gutierrez-Alonso, G.; Nance, R. D.; Fernandez-Suarez, J.; Keppie, J. D.; Quesada, C.; Strachan, R. A.; and Dostal, J. 2006. Origin of the Rheic Ocean: rifting along a Neoproterozoic suture? Geology 34: 325-328.

Murphy, J. B.; Gutiérrez-Alonso, G.; Fernández-Suárez, J.; and Braid, J. A. 2008. Probing crustal and mantle lithosphere origin through Ordovician volcanic rocks along the Iberian passive margin of Gondwana. Tectonophysics 461:166-180.

Murphy, J. B.; Cousens, B. L.; Braid, J. A.; Strachan, R. A.; Dostal, J.; Keppie, J. D.; and Nance, R. D. 2011. Highly depleted oceanic lithosphere in the Rheic Ocean: implications for Paleozoic plate reconstructions. Lithos 123:165-175.

Nance, R. D.; Gutiérrez-Alonso, G.; Keppie, J. D.; Linnemann, U.; Murphy, J. B.; Quesada, C.; Strachan, R. A.; and Woodcock, N.H. 2010. Evolution of the Rheic Ocean. Gondwana Res. 17:194-222.

Naud G., and Pittau Demelia, P. 1987. Premiere decouverte d'acritarches du Cambrien moyen à superieur basal et du Tremadoc-Arenigien dans la basse vallée du Flumendosa: mise en evidence d'un nouveau té- moin de la Phase Sarde en Sardaigne orientale. IGCP Newsl. no. 5, 7:85-86.

Navidad, M.; Castiñeiras, P.; Casas, J. M.; Liesa, M.; Fernández Suárez, J.; Barnolas, A.; Carreras, J.; and GilPeña, I. 2010. Geochemical characterization and isotopic age of Caradocian magmatism in the northeastern Iberian Peninsula: insights into the Late Ordovician evolution of the northern Gondwana margin. Gondwana Res. 17:325-337.

Oggiano, G.; Gaggero, L.; Funedda, A.; Buzzi, L.; and Tiepolo, M. 2010. Multiple early Palaeozoic volcanic events at the northern Gondwana margin: U-Pb age evidence from the Southern Variscan branch (Sardinia, Italy). Gondwana Res. 17:44-58.

Oggiano, G., and Mameli, P. 2006. Diamictite and oolitic ironstones, a sedimentary association at OrdovicianSilurian transition in the north Gondwana margin: new evidence from the inner nappe of Sardinia Variscides (Italy). Gondwana Res. 9:500-511.

Pearce, J. A. 1983. The role of subcontinental lithosphere in magma genesis at destructive plate margins. In Hawkesworth, C. J., and Norry, M. J., eds. Continental basalts and mantle xenoliths. Nantwhich, Shiva, p. 230-249.

Pearce, J. A.; Harris, N. B. W.; and Tindle, A. G. 1984. Trace element discrimination diagrams for the tectonic interpretation of granitic rocks. J. Petrol. 25:956983.

Piçarra, J. M.; Robardet, M.; Bourahrouh, A.; Paris, F.; Pereira, Z.; Lemenn, J.; Gouvernnec, R.; Oliveira, J. T.; and Lardeux, H. 2002. Le passage Ordovicien-Silurien et la partie inférieure du Silurien (Sud-Est du Massif armoricain, France). C. R. Geosci. 334:11771183.

Pillola, G. L.; Leone, F.; and Loi, A. 1995. The Lower Cambrian Nebida Group of Sardinia. Rend. Semin. Fac. Sci. Univ. Cagliari 65:27-60.

Pin, C.; Kryza, R.; Oberc-Dziedzic, T.; Mazur, S.; Turniak, K.; and Waldhausrová, J. 2007. The diversity and geodynamic significance of late Cambrian (ca. $500 \mathrm{Ma}$ ) felsic anorogenic magmatism in the northern part of the Bohemian Massif: a review based on Sm-Nd isotope and geochemical data. In Linnemann, U.; Nance, D.; Kraft, P.; and Zulauf, G., eds. The evolution of the Rheic ocean: from Avalonian-Cadomian active margin to Alleghenian-Variscan collision. Geol. Soc. Am. Spec. Pap. 423:287-296.

Pin, C., and Lancelot, J. 1982. U-Pb dating of an early Paleozoic bimodal magmatism in the French Massif Central and of its further metamorphic evolution. Contrib. Mineral. Petrol. 79:1-12.

Pin, C., and Marini, F. 1993. Early Ordovician continental break-up in Variscan Europe: Nd-Sr isotope and trace element evidence from bimodal igneous associations of the southern Massif Central, France. Lithos 29:177196.

Ricci, C.A., and Sabatini, G. 1978. Petrogenetic affinity and geodynamic significance of metabasic rocks from Sardinia, Corsica and Provence. Neues Jahrb. Geol. Palaeontol. Monatshefte 1:23-38. 
Robardet, M. 2003. The Armorica "microplate": fact or fiction? critical review of the concept and contradictory paleobiogeographical data. Palaeogeogr. Palaeoclimatol. Palaeoecol. 195:125-148.

Rossi, P.; Oggiano, G.; and Cocherie, A. 2009. A restored section of the "southern Variscan realm" across the Corsica-Sardinia microcontinent. C. R. Geosci. 341: 224-238.

Rudnick, R. L., and Fountain, D. M. 1995. Nature and composition of the continental crust: a lower crustal perspective. Rev. Geophys. 33:267-309.

Sánchez-García, T.; Bellido, F.; and Quesada, C. 2003. Geodynamic setting and geochemical signatures of Cambrian-Ordovician rift-related igneous rocks /OssaMorena Zone, SW Iberia). Tectonophysics 365:233255.

Stampfli, G. M.; von Raumer, J.; and Borel, G. D., 2002. The Palaeozoic evolution of pre-Variscan terranes: from Gondwana to the Variscan collision. In Martinez-Catalan, J. R.; Hatcher, R. D.; Arenas, R.; and Diaz Garcia, F., eds. Variscan-Appalachian dynamics: the building of the late Palaeozoic basement. Geol. Soc. Am. Spec. Pap. 364:263-280.

Sun, S. S., and McDonough, W. F. 1989. Chemical and isotopic systematies of oceanic basalts: implications for mantle composition and processes. In Saunders, A. D., and Norry, M. J., eds. Magmatism in the ocean basins. Geol. Soc. Spec. Publ. 42:313-345.
Tsikalas, F.; Faleide, J. I.; and Kusznir, N. J. 2008. Alongstrike variations in rifted margin crustal architecture and lithosphere thinning between northern Vøring and Lofoten margin segments off mid-Norway. Tectonophysics 458:68-81.

von Raumer, J. F.; Stampfli, G. M.; and Bussy, F. 2003. Gondwana derived microcontinents: the constituents of the Variscan and Alpine collisional orogens. Tectonophysics 365:7-22.

von Raumer, J. F., and Stampfli, G. M. 2008. The birth of the Rheic Ocean-Early Palaeozoic subsidence patterns and subsequent tectonic plate scenarios. Tectonophysics 461:9-20.

Voss, M.; Schmidt-Aursch, M. C.; and Jokat, W. 2009. Variations in magmatic processes along the East Greenland volcanic margin. Geophys. J. Int. 177:755782.

Weaver, B., and Tarney, J. 1984. Empirical approach to estimating the composition of the continental crust. Nature 310:575-577.

Winchester, J. A., and Floyd, P. A. 1977. Geochemical discrimination of different magma series and their differentiation products using immobile elements. Chem. Geol. 20:325-343.

Zen, E. 1988. Phase relations of peraluminous granitic rocks and their petrogenetic implications. Annu. Rev. Earth Planet. Sci. 16:21-52. 


\section{Appendix from L. Gaggero et al., "Rifting and Arc-Related Early Paleozoic Volcanism along the North Gondwana Margin: Geochemical and Geological Evidence from Sardinia (Italy)"}

(J. Geol., vol. 120, no. 3, p. 273) 
APPENDIX FROM L. GAGGERO ET AL., PALEOZOIC VOLCANISMS IN NORTH GONDWANA

\section{Supplemental Figures}

\begin{tabular}{|c|c|c|c|c|c|c|}
\hline Epoch & Sample name & $\begin{array}{l}\text { Occurrence and rock } \\
\text { classification } \\
\text { (Winchester and Floyd, 1977) }\end{array}$ & $\begin{array}{l}\text { Locality, GPS } \\
\text { coordinates }\end{array}$ & $\begin{array}{c}\text { Variscan } \\
\text { Nappe } \\
\text { Zone }\end{array}$ & $\begin{array}{c}\text { Tectonic Unit } \\
\text { CARG } 549 \text { Muravera, } \\
\text { Oggiano and Mameli } \\
(2006)\end{array}$ & Symbol \\
\hline \multirow{9}{*}{ 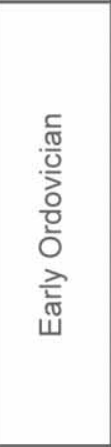 } & ORD1 & \multirow{2}{*}{$\begin{array}{l}\text { trachyandesite pyroclastic } \\
\text { fall deposit } \\
\end{array}$} & Bruncu su Pomposu & \multirow{5}{*}{ 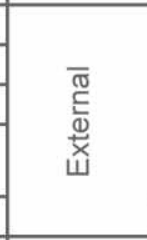 } & \multirow{4}{*}{ Sarrabus } & \multirow{4}{*}{ - } \\
\hline & ORD2 & & Case Meloni & & & \\
\hline & ORD6 & trachyte lava flow & Bruncu is Zarpas & & & \\
\hline & $\begin{array}{l}\text { ORD17,18,19, } \\
\text { OD27-33 }\end{array}$ & $\begin{array}{l}\text { rhyolite / comenditic } \\
\text { trachyte ignimbrite }\end{array}$ & Minderri & & & \\
\hline & ORD25 & \begin{tabular}{|c|} 
dacite lava flow \\
\end{tabular} & $32 S 0524980,4401109$ & & Meana Sardo & $\star$ \\
\hline & ORD34,35 & $\begin{array}{c}\text { dacite / trachyandesite lava } \\
\text { flow } \\
\end{array}$ & Geisgia Mts. & \multirow{4}{*}{ 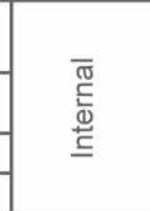 } & Canaglia & it \\
\hline & ORD38,40 & subalkali basalt lava flow & $\begin{array}{c}\text { Madragassa - La } \\
\text { Chintana Road }\end{array}$ & & \multirow{3}{*}{ Li Trumbetti } & \multirow{3}{*}{$\mathrm{O}$} \\
\hline & ORD45,47 & \multirow{2}{*}{ comendite lava flow } & Li Trumbetti & & & \\
\hline & ORD48 & & La Colti & & & \\
\hline \multirow{14}{*}{ 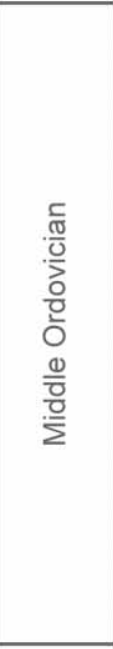 } & ORD12 & andesite dyke & Porto Corallo & \multirow{11}{*}{$\begin{array}{l}\bar{\pi} \\
\stackrel{\frac{\pi}{0}}{\mathbb{x}} \\
\text { ய }\end{array}$} & \multirow{5}{*}{ Sarrabus } & \multirow{5}{*}{$\boldsymbol{\Delta}$} \\
\hline & OD2 & pyroclastic andesite & Su Muizzoni (Villasalto) & & & \\
\hline & OD3 & andesite flow & Su Muizzoni & & & \\
\hline & OD4, 5 & andesite flow & Su Muizzoni & & & \\
\hline & OD6 & rhyolite pyroclastite & Su Muizzoni & & & \\
\hline & OD13,14, 15 & andesite tuff & Rocca dei Nuxi & & \multirow{6}{*}{ Gerrei } & \multirow{6}{*}{$\nabla$} \\
\hline & OD16, 17 & dacite pyroclastite & Rocca dei Nuxi & & & \\
\hline & OD 11-12 & rhyolite pyroclastite & Rocca dei Nuxi & & & \\
\hline & OD19, 20 & rhyolite ignimbrite & & & & \\
\hline & OD7, 8, 9 & basalt & \begin{tabular}{|c|} 
Arcu de Su Bentu \\
\end{tabular} & & & \\
\hline & OD34,35 & dacite ignimbrite & $\begin{array}{l}\text { Sarrabus grey Porphyroid } \\
\text { fm. }\end{array}$ & & & \\
\hline & OD36-38 & andesite, dacite tuff & \begin{tabular}{|c|}
$\begin{array}{c}\text { Foresta Burgos, } \\
\text { crossroad to Frida }\end{array}$ \\
\end{tabular} & \multirow{3}{*}{ 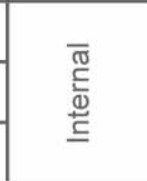 } & \multirow{3}{*}{ Goceano } & \multirow{3}{*}{$\nabla$} \\
\hline & OD39-40 & rhyolite & $\begin{array}{c}\text { Porphyroid fm. (close to } \\
\text { Foresta Burgos) }\end{array}$ & & & \\
\hline & OD41-44, 45, 46 & rhyolite & $\begin{array}{c}\text { Foresta Badu Idda } \\
\text { towards Mt. Pisano } \\
\end{array}$ & & & \\
\hline \multirow{14}{*}{$\begin{array}{l}\frac{c}{0} \\
\frac{\pi}{0} \\
\frac{0}{2} \\
\frac{0}{0} \\
0 \\
\frac{1}{0} \\
\frac{0}{0} \\
\frac{0}{2}\end{array}$} & B8 & pillow trachyandesite lava & Minderri & \multirow{8}{*}{$\begin{array}{l}\overline{0} \\
\text { c } \\
\text { d } \\
\text { ய } \\
\text { W }\end{array}$} & Sarrabus & $\square$ \\
\hline & ORD32 & \multirow{2}{*}{ alkali basalt lava flow } & $\begin{array}{c}32 S 0522501,4375232 \\
\text { Silius Mine }\end{array}$ & & \multirow{2}{*}{ Gerrei } & \multirow{2}{*}{$\square$} \\
\hline & OD21-26 & & & & & \\
\hline & OD47-49 & $\begin{array}{c}\text { metabasalt (amphibolite } \\
\text { facies) }\end{array}$ & Mt. Pisano & & \multirow{5}{*}{ Meana Sardo } & \multirow{5}{*}{$x$} \\
\hline & EB38 & & Porta Eccia & & & \\
\hline & ORD22,23,24 & alkali basalt dyke & Escalaplano Village & & & \\
\hline & ORD29 & & $32 S$ 0524665, 4401154 & & & \\
\hline & ORD9,11 & $\begin{array}{c}\text { pillow trachyandesite / } \\
\text { dacite lava }\end{array}$ & Bruncu Nieddu & & & \\
\hline & ORD41 & alkali gahbro & Road to La Chintana & & & \\
\hline & ORD42 & alkall gaboro & Road to La Chintana & & Canaglia & + \\
\hline & ORD36 & & Geisgia Mts. & $\overline{\widetilde{\mathbb{O}}}$ & canagira & $T$ \\
\hline & ORD43 & & Villaggio Nurra & $\stackrel{5}{ \pm}$ & & \\
\hline & ORD44 & alkali basalt sill & Li Trumbetti & & & \\
\hline & ORD37 & & $\begin{array}{c}\text { Madragassa - La } \\
\text { Chintana Road }\end{array}$ & & Li Trumbetti & 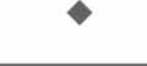 \\
\hline
\end{tabular}

Figure A1. Occurrences of Ordovician volcanic rocks in the Sardinian nappes and tectonic units, and sampling locations. 


\begin{tabular}{|c|c|c|c|c|c|c|c|c|c|c|c|c|c|c|}
\hline \begin{tabular}{c|}
$\begin{array}{c}\text { Assumed } \\
\text { age }\end{array}$ \\
\end{tabular} & Tectonic Unit & Lithology & Sample & ${ }^{87} \mathrm{Sr}^{86} \mathrm{Sr} r_{\text {meas }} \pm 2 \sigma$ & $\mathrm{Rb} / \mathrm{Sr}$ & ${ }^{87} \mathrm{Rb}{ }^{\beta 6} \mathrm{Sr}$ & ${ }^{87} \mathrm{Sr}^{86} \mathrm{Sr}_{\text {intital }}$ & $\varepsilon \mathrm{Sr}_{\text {intial }}$ & ${ }^{143} \mathrm{Nd} /{ }^{144} \mathrm{Nd} d_{\text {meas }} \pm 2 \sigma$ & $\mathrm{Sm} / \mathrm{Nd}$ & ${ }^{147} \mathrm{Sm} /{ }^{144} \mathrm{Nd}$ & ${ }^{143} \mathrm{Nd} /{ }^{144} \mathrm{Nd} d_{\text {intal }}$ & $\varepsilon N d_{\text {initial }}$ & $T_{D M}(\mathrm{Ga})$ \\
\hline \multirow{9}{*}{$490 \mathrm{Ma}$} & & \multirow{2}{*}{ basalt } & ORD38 & $0,758500 \pm 17$ & 3,286 & 9,5536 & 0,69179 & $-172,4$ & $0,511911 \pm 24$ & 0,189 & 0,1144 & 0,511544 & $-9,04$ & 1,88 \\
\hline & & & ORD40 & $0,778763 \pm 23$ & 4,833 & 14,0813 & 0,68044 & $-333,7$ & $0,511882 \pm 21$ & 0,177 & 0,1069 & 0,511539 & $-9,14$ & 1,88 \\
\hline & & dacite & ORD34 & $0,764966 \pm 18$ & 4,125 & 12,0015 & 0,68117 & $-323,4$ & $0,512145 \pm 21$ & 0,207 & 0,1254 & 0,511743 & $-5,16$ & 1,57 \\
\hline & & trachy-andesite & ORD35 & $0,726769 \pm 23$ & 1,376 & 3,9877 & 0,69893 & $-71,1$ & $0,512618 \pm 21$ & 0,283 & 0,1713 & 0,512068 & 1,20 & 1,07 \\
\hline & & \multirow{2}{*}{ comendite } & ORD45 & $0,732483 \pm 17$ & 1,900 & 5,5105 & 0,69401 & $-150,0$ & $0,512585 \pm 24$ & 0,295 & 0,1783 & 0,512013 & 0,12 & 1,16 \\
\hline & & & ORD48 & $0,730963 \pm 25$ & 1,704 & 4,9413 & 0,69646 & $-106,1$ & $0,512555 \pm 26$ & 0,263 & 0,1590 & 0,512045 & 0,74 & 1,11 \\
\hline & Meana Sardo & dacite & ORD25 & $0,722168 \pm 21$ & 0,556 & 1,6106 & 0,71092 & 99,3 & $0,512063 \pm 20$ & 0,201 & 0,1219 & 0,511672 & $-6,54$ & 1,68 \\
\hline & \multirow[t]{2}{*}{ Sarrabus } & \multirow{2}{*}{ rhyolite } & OD31 & $0,807828 \pm 20$ & 8,097 & 23,6566 & 0,64265 & $-870,5$ & $0,512653 \pm 22$ & 0,266 & 0,1610 & 0,512136 & 2,53 & 0,97 \\
\hline & & & OD 33 & $0,713985 \pm 26$ & 0,358 & 1,0354 & 0,70676 & 40,1 & $0,512598 \pm 23$ & 0,271 & 0,1642 & 0,512071 & 1,25 & 1,07 \\
\hline \multirow{4}{*}{$465 \mathrm{Ma}$} & \multirow{2}{*}{ Meana Sardo } & andesite & OD36 & $0,711060 \pm 20$ & 0,098 & 0,2846 & 0,70917 & 74,1 & $0,512196 \pm 20$ & 0,169 & 0,1025 & 0,511884 & $-3,03$ & 1,39 \\
\hline & & \multirow{2}{*}{ dacite } & OD38 & $0,714396 \pm 19$ & 0,343 & 0,9934 & 0,70781 & 54,8 & $0,512143 \pm 24$ & 0,189 & 0,1143 & 0,511795 & $-4,77$ & 1,52 \\
\hline & Gerrei & & OD35 & $0,722630 \pm 20$ & 0,668 & 1,9359 & 0,70981 & 83,0 & $0,512124 \pm 23$ & 0,206 & 0,1246 & 0,511745 & $-5,75$ & 1,60 \\
\hline & Sarrabus & andesite & ORD12 & $0,715861 \pm 21$ & 0,270 & 0,7829 & 0,71067 & 95,4 & $0,512206 \pm 20$ & 0,207 & 0,1252 & 0,511825 & $-4,18$ & 1,48 \\
\hline \multirow{12}{*}{$440 \mathrm{Ma}$} & & \multirow{10}{*}{$\begin{array}{c}\text { alkali } \\
\text { (meta)basalt / } \\
\text { gabbro }\end{array}$} & ORD37 & $0,708471 \pm 14$ & 0,001 & 0,0019 & 0,70846 & 63,5 & $0,512612 \pm 19$ & 0,206 & 0,1246 & 0,512253 & 3,55 & 0,85 \\
\hline & Canaglia & & ORD42 & $0,705405 \pm 21$ & 0,012 & 0,0358 & 0,70518 & 16,9 & $0,512548 \pm 22$ & 0,226 & 0,1369 & 0,512153 & 1,61 & 1,00 \\
\hline & & & ORD36 & $0,707115 \pm 20$ & 0,006 & 0,0151 & 0,70702 & 38,7 & $0,512597 \pm 14$ & 0,209 & 0,1267 & 0,512232 & 3,14 & 0,88 \\
\hline & & & ORD43 & $0,706303 \pm 20$ & 0,029 & 0,0781 & 0,70581 & 21,6 & $0,512638 \pm 23$ & 0,215 & 0,1300 & 0,512263 & 3,75 & 0,83 \\
\hline & Li Trumbetti & & ORD44 & $0,715031 \pm 21$ & 0,185 & 0,4977 & 0,71191 & 108,2 & $0,512594 \pm 18$ & 0,229 & 0,1383 & 0,512195 & 2,42 & 0,94 \\
\hline & Goceano & & OD49 & $0,713563 \pm 22$ & 0,075 & 0,2162 & 0,71221 & 116,8 & $0,512576 \pm 25$ & 0,189 & 0,1142 & 0,512247 & 3,43 & 0,86 \\
\hline & \multirow{2}{*}{ Gerrei } & & OD26 & $0,711240 \pm 30$ & 0,082 & 0,2203 & 0,70986 & 79,0 & $0,512673 \pm 23$ & 0,246 & 0,1490 & 0,512244 & 3,37 & 0,86 \\
\hline & & & ORD32 & $0,733247 \pm 28$ & 2,140 & 6,2070 & 0,69434 & $-137,0$ & $0,512543 \pm 23$ & 0,200 & 0,1210 & 0,512194 & 2,41 & 0,94 \\
\hline & \multirow{3}{*}{ Meana Sardo } & & ORD23 & $0,710296 \pm 22$ & 0,096 & 0,2785 & 0,70855 & 64,8 & $0,512560 \pm 26$ & 0,233 & 0,1412 & 0,512153 & 1,60 & 1,00 \\
\hline & & & ORD29 & $0,713493 \pm 23$ & 0,017 & 0,0488 & 0,71319 & 130,7 & $0,512520 \pm 18$ & 0,201 & 0,1213 & 0,512170 & 1,94 & 0,98 \\
\hline & & \multirow{2}{*}{ trachy-andesite } & ORD9 & $0,728317 \pm 18$ & 1,375 & 3,9862 & 0,70333 & $-9,3$ & $0,512154 \pm 23$ & 0,183 & 0,1108 & 0,511835 & $-4,62$ & 1,49 \\
\hline & Sarrabus & & B8 & $0,710350 \pm 20$ & 0,202 & 0,5446 & 0,70694 & 37,5 & $0,512450 \pm 40$ & 0,357 & 0,2161 & 0,511828 & $-4,76$ & 1,50 \\
\hline
\end{tabular}

Figure A2. $\mathrm{Rb}-\mathrm{Sr}$ and $\mathrm{Sm}-\mathrm{Nd}$ concentrations and isotopic analyses for selected samples from the external and internal nappes of Sardinia. 